Portland State University

PDXScholar

\title{
Non-work-related services at the workplace : an exploratory study
}

\author{
William Roland Adix \\ Portland State University \\ Elizabeth March Christie \\ Portland State University \\ James J. Christrup \\ Portland State University \\ Carol M. Kaulukukui \\ Portland State University \\ Jennifer Idris Lenway \\ Portland State University
}

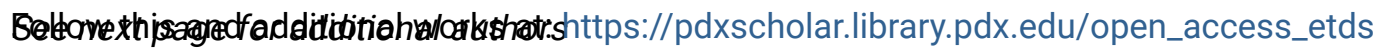

Part of the Social Work Commons, and the Work, Economy and Organizations Commons Let us know how access to this document benefits you.

\section{Recommended Citation}

Adix, William Roland; Christie, Elizabeth March; Christrup, James J.; Kaulukukui, Carol M.; Lenway, Jennifer Idris; Nelson, Cynthia A.; Rielly, Linda S.; Sorlien, Steven; Sweeney-Easter, Kathleen A.; Tate, Lynn Campbell; Warman, Patricia Jones; and Warton, Donn C., "Non-work-related services at the workplace : an exploratory study" (1981). Dissertations and Theses. Paper 3457.

https://doi.org/10.15760/etd.5341

This Thesis is brought to you for free and open access. It has been accepted for inclusion in Dissertations and Theses by an authorized administrator of PDXScholar. Please contact us if we can make this document more accessible: pdxscholar@pdx.edu. 


\section{Author}

William Roland Adix, Elizabeth March Christie, James J. Christrup, Carol M. Kaulukukui, Jennifer Idris Lenway, Cynthia A. Nelson, Linda S. Rielly, Steven Sorlien, Kathleen A. Sweeney-Easter, Lynn Campbell Tate, Patricia Jones Warman, and Donn C. Warton 
AN ABSTRACT OF THE RESEARCH PRACTICUM OF William Roland Adix, Elizabeth March Christie, James J. Christrup, Carol M. Kaulukukui, Jennifer Idris Lenway, Cynthia A. Nelson, Linda S. Rielly, Steven Sorlien, Kathleen A. Sweeney-Easter, Lynn Campbell Tate, Patricia Jones Warman, and Donn C. Warton for the Master of Social Work presented June 1, 1981.

Title: Non-Work-Related Services at the Workplace: An Exploratory Study.

APPROVED BY THE RESEARCH PRACTICUM ADVISOR:

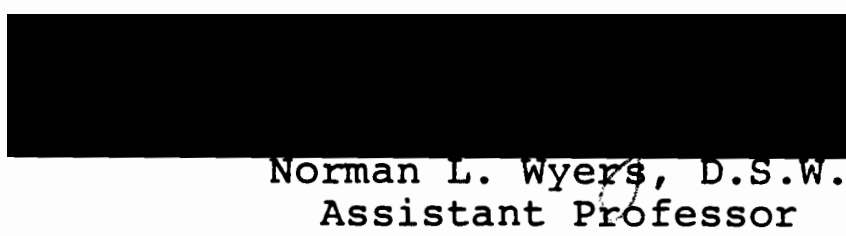

In an era of diminishing public funds, the profession of social work is looking more and more toward the private sector as an arena for social work practice. Social work has had a long-standing interest in the impact of work and the workplace on the individual. This study was developed in response to the lack of documentation of non-work-related services in Oregon's businesses and industries. The research team set out to discover what non-work-related services are 
available to employees at or through the workplace in the TriCounty area (Multnomah, Clackamas, and Washington Counties) of Oregon. This study was exploratory, similar to one done by Hans Spiegel and colleagues in 1974, through Hunter College in New York City.

Non-work-related services were defined as those services (offered at or through the workplace) which emphasize the off-the-job role of the employee as person rather than the on-the-job productive capacity of the person as employee. Drawing from Spiegel's study, these services were grouped into eight categories: recreation and entertainment, education, workplace amenities, community service, information and exchange, individual and family assistance, economic enhancement, and self-actualization.

Sixty worksites were selected, according to criteria of type and size. The types of worksites selected included private nonprofit, private-for-profit, social services, educational, and governmental. The sizes chosen were small (less than 250 employees), medium (250-999 employees), and large (over 1,000 employees).

An interview schedule was developed by a three-member committee. This schedule included questions on what non-workrelated services were offered, how services were financed, and what barriers existed to providing services. Standard procedures were developed for worksite contact, interviewing, and follow up. Interviews were conducted by each of the 12 
research team members. At each site, interviews were conducted with from one to three persons representing management, nonmanagement, and union. In all cases the management level person was interviewed. These interviews were conducted in person at the worksite.

of the 60 worksites selected, 52 participated in the study. This is a compliance rate of 87 percent. In total, 111 interviews were conducted.

The research team located 1,189 unduplicated, non-workrelated services at the 52 worksites. This number includes 219 recreation services, 153 information and exchange services, 221 workplace amenities, 82 self-actualization services, 113 individual and family assistance services, and 120 economic enhancement services. Of the 1,189 services, 19 percent are concentrated in the category of workplace amenities. Recreation services and workplace amenities have nearly equal availability, with means of 4.2 and 4.3 services per worksite, respectively. Information and exchange services are found in 47 (90 percent) of the 52 worksites. These three service types best exemplify the unduplicated services available at the 52 worksites. Their availability may be related to the fact that these services are low cost, low maintenance, and generally non-controversial.

The average number of unduplicated services by worksite category is 23. Private-for-profit and educational worksites exceed the average, with 41 and 28 , respectively. Small 
organizations have the lowest average number of services and large organizations the highest (35). Large, privatefor-profit, unionized organizations offer the most services in any category. The smallest number of services is found in small, nonprofit, nonunionized worksites.

Sixty-six percent of the services at all sites are paid for by the employer. Managers identify lack of money as the major barrier to providing services. The second most frequently sited barrier is a lack of interest on the part of management, staff, and/or union.

It is evident that workplaces in the Tri-County area have assumed a role in providing non-work-related services. Disagreement exists, however, as to the degree and breadth of this role. Barriers to service provision, especially lack of money, lack of interest, and concerns about the appropiateness of some services at the worksite, exist uniformly throughout the worksites. 
NON-WORK-RELATED SERVICES AT THE WORKPLACE:

AN EXPLORATORY STUDY

by

WILLIAM ROLAND ADIX

ELIZABETH MARCH CHRISTIE

J AMES J . CHRISTRUP

CAROL M. KAULUKUKUI

JENNIFER IDRIS LENWAY

CYNTHIA A. NELSON

LINDA S. REILLY

STEVEN SORLIEN

KATHLEEN A. SWEENEY-EASTER

LYNN CAMPBELL TATE

PATRICIA JONES WARMAN

DONN C. WARTON

A practicum submitted in partial fulfillment of the requirements for the degree of

MASTER OF SOCIAL WORK

Portland State University

1981 
TO THE OFFICE OF GRADUATE STUDIES AND RESEARCH:

Approval given the research practicum of William Roland Adix, Elizabeth March Christie, James J. Christrup, Carol M. Kaulukukui, Jennifer Idris Lenway, Cynthia A. Nelson, Linda S. Reilly, Steven Sorlien, Kathleen A. Sweeney-Easter, Lynn Campbell Tate, Patricia Jones Warman, and Donn C. Warton presented June 1, 1981.

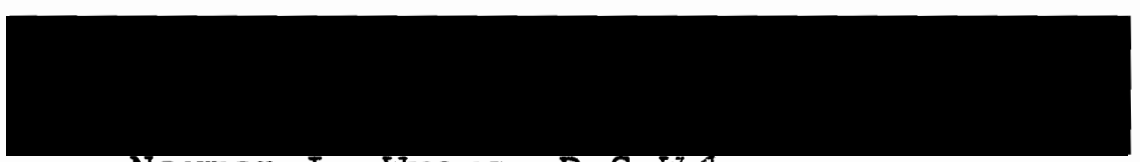

Norman L. Wyers, D.S.W.

Assistant Professor

APPROVED :

Head, Department of Social Work

Dean of Graduate Studies and Research 


\section{ACKNOWLEDGEMENTS}

The research team would like to thank Dr. Norman Wyers, our consultant in this research, for his guidance and advice.

We are also grateful to Dr. Robert Holloway for his technical assistance on the questionnaire and the computer.

Special thanks are offered as well to Cynthia Nelson, who coordinated the entire project with patience and understanding.

Finally, we are grateful to the many people in the community who gave freely of their time and expertise while we conducted our research and interviews. 
TABLE OF CONTENTS

PAGE

ACKNOWLEDGEMENTS . . . . . . . . . . . . . . . . iii LIST OF TABLES . . . . . . . . . . . . . . . . . . vi vi CHAPTER

I RESEARCH RATIONALE ............ 1

II LITERATURE REVIEW . . . . . . . . . . 4

Introduction . . . . . . . . . . 4

Perspectives on Work . . . . . . . 4

Work in America . . . . . . . . 13

Role of Social Work in Industry . . . . 22

Issues in Industrial Social Work . . . 33

Effectiveness . . . . . . . . . . . 44

Summary . . . . . . . . . . 52

III METHODOLOGY . . . . . . . . . . 56

Introduction .......... . 56

The Tri-County Study . . . . . . . 57

The Interview Schedule . . . . . . 61

Collection of the Data . . . . . . 65

Interviewing ........... . 67

Coding . . . . . . . . . . . 70

Reliability and Validity . . . . . 72

Strengths and Limitations . . . . . 75 
CHAPTER

PAGE

Summary • • • • • • • • • • • • • 77

IV FINDINGS AND ANALYSIS . • . . . . • . . . . 78

Introduction . . . . . . . . . . 78

Turnover Rate, Community Involvement, and

Female Representation . . . . . . 83

Number of Services . . . . . . . . 86

Comparisons . . . . . . . . . . . 100

Summary • • . . . . . . . . • . . 106

V IMPLICATIONS OF THE WORKSITE STUDY • • • • • 107

SELECTED BIBLIOGRAPHY • • • • • . • . • • • • • . . 113

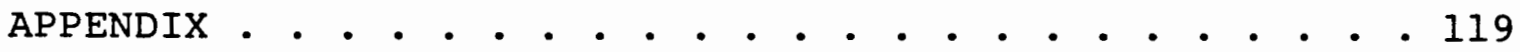


LIST OF TABLES

TABLE

PAGE

I Reasons for the Elimination of Selected Worksites . . . . . . . . . . . . 66

II Number and Percentage of Workers According to Worksite Size . . . . . . . . . . 80

III Number and Percentage of Worksites, in Rank Order, According to Type . . . . . . . 81

IV Number and Percentage of Unduplicated Services, in Rank Order, According to Service Category . . . . . . . . . .

$\mathrm{V}$ Mean Number of Services per Worksite, in Rank Order, According to Service Category . .

VI Number and Percentage of Barriers in Initia-

ting Non-Work-Related Services, in Rank

Order, as Reported by 52 Managers . . . .

VII Number and Percentage of Desired Additional

Services, in Rank Order, As Reported by 52 Managers . . . . . . . . . . . . 96

VIII Number and Percentage of Problems which Could Be Addressed at the Worksite, in Rank Order, As Reported by 52 Managers . . . .

IX Number and Mean Number of Unduplicated Services by Worksite Type . . . . . . . 101 
vii

TABLE

PAGE

$x$ Number and Mean Number of Unduplicated Services by Union Affiliation . . . . . . . 103

XI Number and Mean Number of Unduplicated Services by Size of Worksite ........... 105 
CHAPTER I

\section{RESEARCH RATIONALE}

The emerging field of industrial social work focuses on the worker within the industrial setting. In defining industrial social work, Akabas, Kurzman, and Kolben refer

to the utilization of social work expertise in meeting the needs of workers or union members and the serving of broader organizational goals of the setting. For social workers, it offers the opportunity to intervene in a multiple of environmental systems that affect the individual. (1979, p. 5)

While social work practice has traditionally been concerned with the welfare of working people, it has only recently entered the work environment itself as an appropriate place for professional activity. A good part of this activity is a result of the growing literature documenting worker dissatisfaction with the worksite and the effects of personal troubles on worker productivity. Changes in American society have also altered the ways in which people satisfy their economic, social, and psychological needs (McLean, 1966). That is, as the extended family becomes less accessible to people for support, the worksite takes on greater importance as psychological and social resources for employees. When the organization concerns itself solely with efficient means of production and ignores workers' expectations of the worksite, dissatisfaction arises. Akabas and Weiner, citing the 
1971 Health, Education, and Welfare (HEW) task force entitled Work In America, state that

the documentation suggests not only that many of the generalized problems of American society stem from the work institutions, but more specifically, that untold personal and mental health problems of working Americans have their roots in the world of work and can be resolved in that arena. (1974, p. 2)

Work institutions are suffering significant economic losses due to employees with problems. Not all problems have a direct causal relationship to the work environment. However, private matters often manifest themselves at the workplace as declining or irregular job performance, and the workplace can contribute to the intensification of those problems.

Googins (1975), in his discussion of Employee Assistance Programs, states that business is finally beginning to commit itself to national social problems, and is focusing on the human and financial losses of employees. Employees and public interest groups are pressing business and industry to recognize that there is more to business than productivity. A survey of upper and lower management personnel of American Management Association in New York City shows that 90 percent of those surveyed think corporations should deal with the total employee, not just with daily output of that organization (Googins, 1975).

During the past decade, there has emerged some descriptive literature on a handful of social work programs in different industries. These programs are discussed in more 
detail in Chapter II. Most of these programs serve large corporations and conglomerates in the eastern part of the United States. There is little or no literature on the. scope of industrial social work in the Northwest, particularly in Oregon. With the exception of Lee's evaluative study of the Columbia Assistance Program for Employees in Clackamas County (1979), there seems to be no documentation on social service programs in oregon's businesses and industries.

The purpose of this research study is to conduct an exploratory study of services that are currently being provided at or through the worksite. The research team addresses the question: "What non-work-related services are available in the Tri-County area of Multnomah, Clackamas, and Washington Counties in Oregon?"

This study is only a beginning. The research team is hopeful that future research will expand on the foundation data presented in this project. 
CHAPTER II

\section{LITERATURE REVIEW}

\section{INTRODUCTION}

This chapter reviews the existing literature on the subjects of work and services in the workplace. To accomplish this task, the chapter is divided into four sections. The first section includes a brief historical sketch of the meaning of work and a discussion of the psychological and sociological implications of work. Section two focuses on work in America. Included in this section are demographic data on work and workers and the cultural role of work in this society. The focus of section three is the role social work has played in the workplace, followed by a section on the social work issues pertinent to the industrial setting. The final section is a review of the existing research on the effectiveness of services in the workplace.

\section{PERSPECTIVES ON WORK}

\section{Historical Perspective}

The definitions of work are as varied as the authors who develop them and as complex as the societies about which these authors write. From the perspective of dictionary definitions, work has most often had a negative connotation 
(Braude, 1975; Neff, 1968; Levitan, 1973). For example, the word "labor" comes from the Latin word meaning "distress or difficulty"; "occupation," also from the Latin, means "to seize hold or grapple with." Similarly, in Greek work equals trouble; in Biblical Hebrew, work equals slavery (Braude, 1975). Even in current usage the extensive definition of work provided in Webster's dictionary includes such words as "effort," "labor," "toil," "duty," and "task." All of these words imply that work is something less than voluntary, pleasant activity.

Though work has been viewed historically in a negative frame, there were subtle but significant changes in the Middle Ages that have survived to this day. During the Middle Ages, the Judeo-Christian concept of work began to develop. Work became a basic factor of religious faith. It was the duty of the Christian to work intensively at his/her chosen field. Work became the focus of Christian life. From these changes emerged the phrase "Protestant work ethic." According to the Protestant ethic, economic prosperity was an indication of one's predestined heavenly blessings. To earn wealth through hard work and investment was to be blessed. In contrast, those not wanting or unwilling to work hard were viewed as being the cause of their own economic misery and ran the risk of divine condemnation. Consequently, the values of working when able, working hard, making prudent investments of one's earnings, and using work to gain social 
recognition constitute America's work ethic (Menninghan, 1980; Neff, in Bryant, ed., 1972; Vantil, 1976). The concept of the Protestant work ethic has survived to current times but is now being questioned with increasing frequency (Braude, 1975, Neff, 1968; Terkel, 1980; Berg, in O'Toole, ed., 1974). Many workers view work as essential for survival but not as their most important life activity.

Historical writings on work in ancient societies focus on the types of work and the statuses associated with that work. Work has not always been a separate activity from other life activities. To the primitive hunting and gathering societies, work was an integral part of daily activity. All of the members of the tribe engaged in work at some level (Neff, 1968). Work was an activity that was essential for survival. With the emergence of agriculture and later industrial societies, that concept was altered. Work and leisure were divided into separate activities.

Contemporary America defines work as purposeful activity aimed at producing something useful (O'Toole, 1974). The produced unit of work may be of economic, social, or personal value, or some combination of these values (Steiner, 1972). In discussing work in America, it is important to define what constitutes the labor force and make clear the distinction between work and employment. According to the United States Department of Labor and Statistics (BLS), the labor force consists of persons at least 16 years of age who are either 
employed or unemployed (Westcott, 1978). An employed person is any citizen at least 16 years old who has worked at least one hour per week for pay, or a minimum of 15 hours per week without pay on a family enterprise. This definition also includes the person temporarily absent from work for reason of illness, vacation, labor-management dispute, or personal reasons. An unemployed person is anyone at least 16 years old who is available for and actively seeking employment. The BLS makes a distinction between unemployment and nonemployment, in that a nonemployed person is at least 16 years old and not actively seeking employment (Westcott, 1978). A nonemployed person is considered by the BLS as "not in the labor force."

Most Americans refer to their employment as their work activity, as paid work has come to be an important means of social and personal validation, as well as a means by which people earn money (O'Toole, 1974). For the purpose of this research project, then, work will be used synonymously with employment.

Very little has been written about how people are impacted by their work, about how they are affected by that portion of their daily lives that is known as work (Neff, 1968). What then are some of the psychological factors involved in work? 
Psychological Perspective

For most people in the labor force, work is a central life interest (Braude, 1975). Work is still an activity that humans do to survive, but currently survival is seen from a consumer perspective. In industrialized societies people no longer grow their own food, produce their own clothing, or build their shelters. Instead, people generate income so that they may purchase those commodities. It is necessary to work at something which provides people with financial return in order to function within the social structure (Braude, 1975; Neff, 1968). For this reason, work is often viewed as inescapable. It is the rare individual who successfully functions within a social structure without engaging in some form of work. If we accept the inescapable nature of work in society, how then can we explain why some people are satisfied and happy with their work and some view their work as merely a job that must be endured?

One of the explanations for this phenomenon is the intricate and complex relationship between work and selfconcept. An individual's thoughts about him/herself often determine how he/she views the world. If self-concepts are negative, a person will often be uncertain and unstable in his/her behavior. Self-concept is made up of various attitudes toward the self in relation to other dimensions of life, such as family, social life, physical self, and work self (Tiffany, Cowan, and Tiffany, 1970). In advanced industrial 
societies, with a definite division of labor, individuals often define themselves in relation to their occupations (Braude, 1975; Neff, 1968; Liebow, 1967; Sennet, 1972). Consider, for example, the introductions at a social gathering. The doctor and the judge will most likely be introduced with their respective titles, giving them a position in the social strata. This position is higher than that of the person working on an industrial assembly line who is generally introduced by name only, with no accompanying title. Most people's self-concepts seem higher when they work at jobs which provide them with a reasonable amount of autonomy and in occupations that society defines as desirable and important (Braude, 1975; Neff, 1968; O'Toole, 1974).

With this in mind, it is easier to understand how a person's self-esteem would be higher and more stable if he/ she were a physician rather than an assembly line worker. It would also be higher if he/she were an assembly line worker rather than unemployed (Liebow, 1967; Sennet, 1972). Research has shown that unemployed people are more unhappy, have more psychiatric disorders, and believe their lives are controlled by other forces. The unemployed
...see themselves as undesirable, doubt their own worth, often feel anxious, depressed, and unhappy, and have little faith or confidence in themselves. (Tiffany, Cowan, and Tiffany, 1970)

The image people have of themselves seems to be directly related to what people do as their paid work activity. 
Sociological Perspective

There is more involved in the question of work than the individual psychological factors. While there are social, economic, and political factors as well, this section will focus on the sociological aspects of work. What is it that society contributes to work and work contributes to society (Neff, 1968)? The earlier reference to hunting and gathering tribes is an example of how work shapes society. The social unit of the small nomadic tribe was the consequence of the type of work performed. Each tribe member worked with the others in specialized but interrelated tasks for the tribe's survival. With changes to an agricultural-based, and ultimately an industrial-based society, the emphasis on tribal interdependency also changed. People no longer lived and worked for the survival of the small tribe. As the primary social and economic unit shifted from the tribe to the nuclear family, people have become more isolated and independent from one another. Now work tasks are shaped by the economic and social structure of the community at large. Some of these new structures demand a division of labor (particularly in industrial society) that had not existed in the earlier societies. Consequently, there is an increased need for an inexpensive, unskilled labor force (Braude, 1975). As a result of the needs of changing social structures, work and people's attitudes about it have become the end product of extensive socialization. The process of becoming 
a worker is a developmental process (Erickson, in Sennet, 1977; Neff, 1968). As Erickson points out, much of this socialization begins to occur in the latency period of a child's development and continues through to adult life. As children observe adults' attitudes about work, they begin to develop their own responses. It is precisely this socialization process that creates some of the problems involved in work. A good example of this process is the area of women and work (Neff, 1968; Mill in Sennet, ed., 1977). Male children are taught early in life that they are expected to make a living and that on the basis of paid employment they will be financially independent. Female children, on the other hand, are taught that work is incidental and temporary and that marriage and family are still the goals for them. Though this may be in the process of changing, re-socialization is slow.

Work, and people's attitudes toward it, are a result of the process of development and socialization in childhood, but they are also an ongoing social process in adult life. Socialization does not stop with adulthood. New interpersonal situations are also a part of the socialization process. As an adult worker becomes a part of the work force, he/she becomes a member of a subculture known as workers (Braude, 1975; Neff, 1968). This subculture is further divided into cultures of different types of workers (Braude, 1975; Sennet, ed., 1977; Liebow, 1967; Neff, 1968). Each of these cultures develops its own independent identity with supporting features 
such as language, dress, membership organizations, and an informal association of co-workers called "occupational colleagueships" (Braude, 1975). The colleagueship sets the occupational cultural tone. Consider, for example, the incongruity of the bank president who comes to "work" in blue jeans and with a lunch pail. Membership in colleagueships gives a worker access to the informal privileges of that occupation. Membership also serves to shape the behavior of the worker in that occupation. These social units become an important part of the working person's daily life and an important part of his identity. The structure of the society shapes the role of work and of worker. The implications for the psychological and sociological factors associated with work are often manifest in such factors as worker dissatisfaction and alienation. These implications will be explored in greater detail in the section on work in America.

\section{Summary}

The literature on the psychological and sociological implications of work is extensive and this brief overview cannot incorporate all of that literature. In order to better understand the concept of services in the work place, however, it is important to discuss the implications of work in America. The following section will address the concept of work in America, who works, what they do, and why. 
WORK IN AMERICA

According to the 1978 BLS statistics, appro:imately 63.5 percent of the total noninstitutional population of working age was employed. Statistics that same year revealed an approximate 5.8 percent unemployment rate. The remaining 36.8 percent of the population were considered nonemployed, that is, out of the labor force (Employment and Training Report of the President, 1979, p. 5). Activities of the nonemployed included homemaking, educational pursuits, disability, and retirement from the labor force. The BLS describes 15.2 percent of the nonemployed population as discouraged workers, that is, persons who wanted to work, but believing they could not secure employment, stopped looking for work.

Recent Demographic Changes

Over the last decade, the labor force in the United states has undergone some dramatic changes. One of the major changes has been the increase in the participation of women in the labor market.

In 1968, approximately 42 percent of women over the age of 16 participated in the labor force, and by 1978 that figure had risen to about 50 percent. Further, the rate of participation of married women with small children more than doubled from 1960-1977 (Ozawa, 1980). However, the differences in earnings of men and women were quite large, and 
this gap seems to be increasing. In 1955, the average female earned 64 percent of wages paid to a similarly employed male. By 1970 the figure dropped to 59 percent (O'Toole, 1974). During the same period that women's participation rose 8 percent, the participation by men declined somewhat, from 84 percent in 1968 to approximately 79 percent in 1978. This increased percentage of women in the labor force, especially married women with children, may mean added stress for families whose adult members must divide their attention between work and home. Also, as more and more women seek occupational fulfillment as well as financial return, they are increasingly seeking jobs traditionally held by men. Often this creates conflicts between women and their male colleagues. Such stresses could result in workers bringing family problems to the work place or taking home problems originating from work, thus creating instability and a potential decrease in worker productivity (Ozawa, 1980).

With the establishment of Affirmative Action guidelines, some minorities have been able to secure employment in a wide range of job opportunities. Yet minority workers are still disproportionately unemployed or working at undesirable jobs. The current Employment and Training Report of the President shows that in 1979 there were over twice as many unemployed blacks as unemployed whites (Employment and Training Report of the President, 1980). Those minorities who do work earn far less than their white counterparts. For a large number 
of minority workers, employment serves two important functions. First, obviously, it is a source of income. Second, the workplace is a major battleground for the struggle to achieve social integration, that is, affirmation of their capacity to make social contributions of equal value with everyone else (O'Toole, 1974; Almquist, 1979). For most minority workers, the problem of racial discrimination is often of greater concern than job meaningfulness, job routine, and authoritarian work tasks (O'Toole, 1974).

The percentage of older workers in the labor force is declining. Males, particularly those in the 65 to 69 age range have the greatest impact on the observed decline. In 1960, 58 percent of them had work experience in that year. In 1976, only 39 percent of the men in this age range had had work experience. When older Americans do work past retirement age, most occupy part-time jobs. However, Morse (1979) observes that the decision to leave the labor market is a "yes or no" decision rather than a "more or less" decision. For most elderly Americans, the combined influences of retirement pensions, mandatory retirement policies, health concerns, and difficulty in replacing a lost job make retirement less a personal decision than one based upon compulsory retirement regulations and societal attitudes towards the elderly. It is noted that the self-employed and farm workers are least pressured by the decision of when to retire.

There is little statistical data available on how many older workers of retirement age continue to be employed on 
a part-time or full-time basis. However, it is clear that, due to sophisticated medical technology, there is an increased number of unemployed able-bodied older persons. The number of able-bodied older persons available for and wanting employment is not known.

The decline in the proportion of the employed population is found in the youngest age group as well as in the elderly. Teenagers, ages 16 through 19, are especially affected by trends such as increased job market activity of women and economic changes. In 1978, 58.5 percent of all teenagers were in the labor force. The unemployment rate for this group was 16.3 percent, which accounts for one of the largest groups of job seekers (Employment and Training Report of the President, 1979).

\section{Alienation}

As industrialization brought about the need for highly efficient means of production, specialization of work tasks was developed to insure smooth work flow and a minimum of costs. This process, called functional rationalism by Blauner (1964), forced workers to sacrifice their creative thinking in the service of the efficient operation of large industrial organizations. As workers became more compartmentalized and less involved with the whole organizational process, they tended not to make sense out of their work and became alienated from their jobs (Ozawa, 1980).

Alienation exists when workers are unable to control their immediate work process to develop a sense of 
purpose and function which connect their jobs to the over-all organization of production, to belong to integrated industrial communities, and when they fail to become involved in the activity of work as a mode of personal self-expression. (O'Toole, 1974, p. 22)

Studies indicate that job dissatisfaction is common throughout the American labor force, and that alienation is a major problem among American workers (Wolfbein, 1971). The 1971 HEW task force on work in America, reported that only a small percentage of workers in the country were satisfied with their jobs, that is, satisfaction coming from a sense of achievement, accomplishment, responsibility, and challenge. The task force also found a high correlation between dissatisfaction on the job and mental health problems such as psychosomatic illness, low self-esteem, anxiety, worry, tension, and impaired interpersonal relationships (Wolfbein, 1971). Alienation expresses itself in a number of ways, depending on the nature of the job and the types of people holding these jobs. According to the 1971 HEW report, worker alienation was not found to be associated with a particular demographic trait of age, sex, race, or collar color. Deans (1973) claims that blue collar workers feel more alienated with their employment because it lacks social esteem, is deadended, yields minimum financial return despite hard work, is often boring, and is often unreliable. "Blue collar blues" are expressed in workers' lowered self-esteem and feelings of inferiority. For many, blue collar employment provides neither economic, personal, nor social reward. 
White collar workers are not without problems. Many of these workers report feeling "barred in," powerless, estranged from the decision-making process, and a lack of worker comraderie (Kay, 1974; Schrank, 1979). Most Americans view white collar employment as socially valuable, but many white collar workers report that the view from behind the desk is not always personally rewarding (Schrank, 1979; Neff, 1968). The signs of discontent among this group are high turnover rates, an increase in union membership, lowered productivity, and lowered loyalty to company goals (Akabas and Weiner, 1974). Even management personnel, with their highly paid, privileged status, do not escape feelings of discontent. Many feel caught in the middle between company decisions and line workers, without adequate resources or authority to influence either side. With the current American value on youth, and the ever-changing trends in business and industry, management often feels obsolete far before retirement age. There has been a marked increase in male death rates between 35 and forty years, attributed to personal distress of this group of workers (Akabas and Weiner, 1974).

For minorities, women, youth, and the older workers, job dissatisfaction is intensified by discrimination factors. For these workers, and for minorities in particular, job discrimination has meant that they have little control over a major institution which affects their lives. It is interesting to note that the most dissatisfied group of American workers are young black people in white collar jobs (O'Toole, 
1974). O'Toole speculates that different white and black standards of language, dress, demeanor, and conduct may create conflicts at the worksite and that intimate contacts with whites may reinforce blacks' feelings of discrimination. "For women, the denial of full participation and the unequal treatment in the workforce has reinforced feelings of inferiority and reliance on men for a sense of identity" (Akabas and Weiner, 1974). In general, women have consistently been assigned the lower-paying, lower-status jobs in the economy, regardless of women's education, abilities, and work experience. Surveys indicate that women tend to derive the same satisfaction men do from the intrinsic rewards of work, but that women are twice as likely as men to express dissatisfaction with their current jobs (O'Toole, 1974). Factors such as sex-typing, economic disparities, and dual responsibilities of homemaking and paid work contribute to feelings of discontent. One might say that women are experiencing alienation both in paid and nonpaid work activities. Escaping their work dissatisfaction is difficult because family financial needs often make acquiring any job more important than getting a desired job. In this sense, the plight of working women is similar to that of minority workers. Alienation among older workers stems from discrimination which denies them the opportunity to fully utilize their work abilities and skills. Older workers find themselves at a competitive disadvantage within the labor market, 
as corporate demands for young, highly mobile workers are easily filled. Consequently, older workers feel useless and antiquated. Retirement from the work force was originally a way of relieving the elderly from the long hours and heavy physical labor necessary during the early stages of the industrial revolution (O'Toole, 1974). Today the older workers are retired to relieve the problem of unemployment. Since, for most Americans, retirement at the approximate age of 65 is a requirement rather than an option, many of the elderly are denied economic and psychological rewards of work. Added dissatisfactions arise from the inadequacies of retirement pensions and the lack of available, meaningful employment for those who wish to remain in the labor market. Hence, many retirees view the current labor market as hostile and ungrateful.

The great social movements, including the women's movement, have been influential in forcing Americans to examine the role of work in people's lives. Although the movements have specifically targeted women's work and minorities' roles, the over-all effect has been the expression of alienation from a variety of groups within the labor market.

Attitudes Towards the American Work Ethic

The meaning of being without work has potentially devastating consequences on an individual's perception of him/herself and of others. Reactions range from self-blame to projected blame (anger over economic inequities, "favoritism" 
shown to minorities). Overall, the impact is one of marked social isolation and assured belief in one's failure as a worker and as a person (Wilcocki, 1963; Komarousky, 1971). Over time, some unemployed may lose hope of ever getting jobs and may become part of America's discouraged labor force. Unfortunately for some, the opportunity to work at an alienating job may not be much better than being unemployed. For the most part, able-bodied Americans are expected to sustain their own economic needs through employment. Public sentiment seems to indicate that, if given a choice between employment and income maintenance, able-bodied Americans are morally obliged to seek work. This attitude is reflected in the public's willingness to provide public support to the disabled, retired, dependent children, and short-term unemployed worker. Persons in these categories have "justified" reasons for not seeking employment. However, Americans often take a negative view of public assistance for those "ablebodied" persons who make up the discouraged labor force, or single parents who view child care and homemaking as their major responsibilities. Stringent public welfare policies regarding assistance programs reflect America's general support of the work ethic (Lampman, 1976).

\section{Summary}

Contemporary America is undergoing some significant changes in its work force and in workers' attitudes toward work itself. Expanded roles for women, federally-mandated 
regulations regarding discriminatory hiring practices, and increased longevity due to medical technology and greater attention to health care, have been instrumental in women, minorities, and the older worker participating in the labor market in increasing numbers. This increased participation has resulted in a highly competitive job market, which, in turn, often results in on-the-job and off-the-job stresses. Workers' rising expectations that their jobs provide psychological satisfactions as well as economic return, and industry's general unresponsive stance to these expectations, have created a situation where a large percentage of America's working people are expressing feelings of alienation and frustration with their work environment.

It is within this context that social work as a profession has recently looked at the workplace itself as an arena for social work practice. The following section traces the historical relationship between industry and the social work profession and examines the role social work has played in "humanizing" American industry.

THE ROLE OF SOCIAL WORK IN INDUSTRY

The nature and meaning of work in this country has farreaching implications for the economic security, social status, emotional stability, and overall life satisfaction for individuals and their families. In many instances, the work Americans do literally shapes the structure, organization 
and meaning they attach to their lives, in and out of the home. The quality and quantity of employee work performance and satisfaction is influenced by a myriad of factors, many of which are external to the actual job descriptions and task assignments.

Social work practitioners historically have shown a genuine interest in counseling workers in need and offering consultation to organizations which wanted to fulfill their social responsibilities to employees (Encyclopedia of Social Work, 1977). Social workers, labor, and management are increasing their collaboration for the purpose of addressing the social, economic, and health needs of employee groups. Additionally, the role of the work place in the initiation and/or reinforcement of poor job performance is more frequently viewed as a priority issue deserving a strategy of planned curative intervention.

The historical issues and events which have formulated this alliance will give detail and clarification to the variety of forces contributing to these developments.

\section{History}

Shortly after the turn of the twentieth century, American businessmen, out of necessity, began to exhibit concern for their employees' welfare. Welfare capitalism is the label applied to efforts made by management on behalf of their employees to increase satisfaction with and performance at the workplace. They proposed to make life more satisfying 
to their workers through improvement of working conditions, wage incentive policies based on productivity and merit, and enhancement of workers' free time with educational and recreational amenities (Brandes, 1970).

However, most companies, save for the very largest, were unable to provide more for their employees than a reasonably safe and clean place to work and a modest wage. The people employed to carry out these basic and limited job improvements were called welfare workers. They were employed by the company to serve in the welfare capitalism model and functioned as a liaison between the worker and the company. All too often, however, this employee became nothing more than a tool of the company to promote anti-union policy (Ramirez, 1978). The irony here is that a key element in the growing legitimacy of social work practitioners offering services to the worker would later come as a direct product of labor unions' early interest in the social welfare of their workers. Thus, those who served in this liaison role unwittingly helped to initiate and reinforce a hostile and suspicious attitude among unionists toward social workers.

The relationship of trade unions to the early social welfare representation and the field of social work was initially exemplified by a conflict of basic values. "The social work profession was seen as isolated from and unresponsive to the needs and concerns of the trade-union constituents" (Encyclopedia of Social Work, 1977). Social welfare 
agencies were perceived as philanthropic organizations. They were often dominated by rich businessmen who openly opposed trade unions.

By virtue of its very ideology and values, early social welfare was perceived to be in conflict with the concerns of trade union members. Workers' problems were defined as individual failures, rather than contributed to by the exploitative industrial conditions of the times. The tenet of the times was to provide the benefits of social welfare to children, the blind, disabled (crippled), sick, the old, and the insane.

Early intervention by Jane Addams and others in the settlement house movement of the 1920's, and before, acted to reduce the disaffection of unions and social welfare. This gave the impression of drawing social welfare away from the dominating influence of the employer (Encyclopedia of social Work, 1977).

The incorporation of Sigmund Freud's theories of the unconscious into social casework practice helped to reinforce the notion of individual responsibility for personal problems, consequently focusing away from environmental factors. Social casework practice had sought to improve upon the person's sense of inner well-being, but it did not possess a set of established principles by which to analyze and treat that person.

Negative attitudes toward social workers were eased slightly when a number of social workers unionized. During 
the Depression Era, unionization among social workers became more widespread and strengthened the ties between social welfare and the unions. In 1938, John L. Lewis delivered an address to social workers, cementing their legitimacy in the ranks of labor:

Social workers, whose daily task is to delve into the living condition of America's poor families, have an unequaled opportunity to inspect the social by-products of our industrial system... Organized labor growing up out of the daily needs of people is the most powerful ally of those professionally committed to a humane public welfare and social service program. (Encyclopedia of Social Work, (1977, p. 740)

During World War II, social service programs for unions multiplied. Bertha Reynolds, well known social work theorist and practitioner, directed a social service program for members of the National Maritime Union (Encyclopedia of Social Work, 1977). Additionally, the longshoremen's and painters' unions hired social workers in the early 1940's. Union counseling, as it was termed then, was started by the Labor Division of the War Production Board in 1942. In existence today, it stands out as one of the few programs which employed social workers who offered counseling and community service linkage to union members (Perlis, 1977).

The unions, however, had no monopoly of interest and concern for employees with problems. During the 1950's, a few major companies in the industrial community began to recognize alcoholism as a growing problem among a certain group of employees. The problem of alcoholism became a 
chief concern because of the overt nature of its symptoms. The alcoholic employee became the focus for treatment and rehabilitative interventions by mental health personnel in the community and at the work site. The alcoholic employee was, indeed, costly and unproductive, and industry began to change its attitude regarding the disposition of such a person. The attitude of punishing these employees by firing them began to give way to rehabilitating them, both to restore them to a productive status and to save the company further expenditures arising from the need to train new employees (Blomquist, Gray; and Smith, 1979).

The available literature of events in the 1950's and early 1960's does not add to existing knowledge nor does it reinforce the development of social work industry. In the mid-1960's, a greater number of industrial managers began to appreciate the significant losses of company income incurred by the deficient productivity of the alcoholic employee. In 1972, it was established that three to four percent of any United states work force was alcoholic, costing industry from three to ten million dollars annually in lost income (Blomquist, Gray, and Smith, 1979).

Community social service agencies attempted to respond to this newly-identified problem but did not meet the expectations of the increasing influx of clients. Long waiting lists and conflicts between agency and workers' hours contributed to a decrease in accessibility of services. 
Cultural differences between agency resources and workers' needs acted to deter client-agency contact. Apparent issues of class bias in the provision of quality treatment further alienated the blue collar worker. These divisive and persistent conflicts motivated unions to obtain fiscal benefits through collective bargaining. In addition, they implemented service programs of their own to compensate for the lack of community resources.

The Hughes Act, proposed by the Department of Health, Education, and Welfare (HEW), passed Congress in 1970. This gave HEW "...the responsibility for fostering programs and services in alcohol abuse, prevention, treatment and rehabilitation in private industry" (Heyman, 1971).

Government legislation affecting women, minorities, and the disabled have led to regulations which affect all employers. Greater consumer demands for a voice in corporate policy-making in which the community and work environment are affected have encouraged a new look at "community relations." Job maintenance programs have proliferated and business and labor have sought professional experts for advice and problem solving (Akabas, 1978).

\section{Social Work Developments}

The field of social work itself was engaged in making significant changes during the time business and labor were awakening to the needs of their workers. Throughout this 
period,

"...social work was too busy finding itself, defining its identity, asserting its professionalism, carving out a niche for itself in the marketplace of human service professions and struggling for respect, recognition and renumeration alongside other helping-healing disciplines..." (Perlis, 1978, p. 3)

A split in the professional focus had developed and widened as social workers sought to define the nature of their professional practice. The social caseworkers were aligned with the provision of direct services to individuals, families, and groups. The community organizers, however, were more concerned with the issues of structural reform as the means to alleviate the monumental social, economic, and political disadvantages endured by the poor. The debate continues to this day and is relevant to this discussion of social work in industry. A social worker, whether employed individually by a company, within a company-based program, or as a community agency employee who contracts for services with industry, must contend with clarifying his/her value base in terms of the service provider/community organizer dichotomy. These issues are more completely addressed later in this chapter.

Industrial Social Work and the Employee Assistance Program

Clear definition of "industrial social work" and the "employee assistance programs" (EAP) is necessary at this juncture before proceeding further.

As defined in Chapter I, industrial social work utilizes social work expertise in meeting the needs of workers 
or union members and serving broad organizational goals of the worksite (Akabas, 1978).

The Council on Social Work Education defines social work in industrial settings as

...social services sponsored by 1) industry 2) trade unions or 3 ) community-based services that have a contractual agreement to service the needs of employees of one or several companies.

The range of activities and services included but are not limited to: 1) personal services including substance abuse services 2) training and staff development, 3) consultation to a business or trade union concerning the physical or social environment within the company and 4) activities concerned with the relationship of a company or trade union to the community (CSWE Report, Jan. 1978, p. 14)

Perlis, (1977) describes the role of an industrial social worker as well:

In addition to casework and group work, such a person would need to know a bit about everything, but a lot about labor-management relations, the history and sociology, the subtleties and nuances. A professional industrial social worker would need to know something about all of this, not so much for the purpose of getting involved, but rather for the purpose of avoiding direct involvement in the adversary relationship between labor and management ... (Perlis, 1977, p. 49)

Although in some ways synonymous with the definitions outlined for industrial social work, the EAP is much more narrow in scope, and focuses on the restoration of employee job performance. Googins (1975) explains the nature of an EAP :

EAP is a system for identifying and treating a variety of medical or behavioral problems that might be responsible for an employee's poor job performance. Its main objective is to restore the employee 
to normal work behavior and productivity. By offering an alternative to being fired, EAP can help the employee to be a better producer for his employer as well as to function better as an individual. (Googins, 1975, p. 465)

EAP's have four essential elements: 1) clear policy and procedures regarding implementation of rehabilitation programs and the roles of management and treatment personnel, 2) training for management and supervisors in understanding the philosophy and function of the program and in handling the problem employee, 3) effective and professional provision of services, either directly by EAP staff or by carefully developed information and referral service, and 4) follow-up to assure the utilization and appropriateness of the service for the particular employee (Googins, 1975).

Current Trends

Labor, management, and government are increasingly sharing the responsibility for identifying problem workers in the work environment. Innovative service programs developed at or through the worksite are now helping employees resolve current problem areas.

Historically, social services for the employee, sponsored by labor or management, have primarily targeted the alcoholic employee for treatment. The Hughes Act of 1970 promoted a significant increase in the development of these programs across the nation. However, as programs began to include the provision of services to non-alcoholic employees, 
a significant number of workers began utilizing those services for various personal reasons.

One example is the INSIGHT program initiated by the Kennecott Copper Corporation in Utah in the 1950's. Soon after implementation of an alcohol program through the corporation, the company expanded services to include all employees and their families (Skidmore, Balsam, and Jones, $1974)$.

U. S. Steel Corporation at South Works in Chicago, Illinois, has been utilizing an on-site program model since the mid-1970's. Counseling, linkage services and a 24-hour hot line comprise the program. The role of the social worker emphasizes alternatives to referring employees to community resources as much as possible. Each counselor is trained to have some knowledge about a wide range of services. Where the counselors cannot offer the needed information or other intervention, they will make a referral to community resources. The social work staff then engages in extensive follow-up procedures to insure both the resource utilization and to document the program's effectiveness for accountability to management (Weissman, 1972).

The roles within which social workers may function as they provide services for employees may involve the following: 1) direct counseling and therapy (substance abuse, anxiety, depression, marital and/or parenting difficulties, bereavement), 2) organization of support groups, 3) concrete 
services (housing, legal, financial, child care, medical), 4) consumer advocacy (garnishment, eviction), 5) crisis intervention, and 6) linkage of an individual with community resources (Akabas, 1978).

The role of the social worker may be further expanded to include the function of trainer and educator for supervisory and management personnel. This function accomplishes such diverse objectives as program maintenance (communication and problem solving), new information dissemination (humanizing the workplace) and maintaining positive public relations and visibility of the program.

Progressive managers and union leaders may be responsive to the inclusion of professional social workers as consultants to the firm. The objective of this function would be to sensitize and encourage these people to take substantive action on other in-house and community needs. Successful participation in these activities allow the social worker to manifest the complete extent of their professional values and commitment, i.e., to render services to the individual and foster change in the social and economic institutions which intimately effect social functioning.

\section{ISSUES IN INDUSTRIAL SOCIAL WORK}

In reviewing the role of the social worker in industrial settings, it is necessary to discuss the issues which practitioners have found to be germane in this field. The 
following section is a review of both the generic and the specific issues and dilemmas confronting the industrial social worker.

\section{People Versus Profits}

One of the basic value conflicts between social work practice and the industrial world is the intrinsic differences in goals and purposes.

Concern for the well-being of people, individually and collectively, historically has been social work's trademark. Industry, on the other hand, places its primary value on production and profits" (Bakalinsky, 1980, p. 474)

That is, social workers historically have practiced in settings where the explicit goals and objectives of those settings were consistent with those of the profession. Not so with industry, whose primary purpose is the maintenance of its own health rather than the health of its employees. Bakalinsky (1980) states that how this basic value conflict is resolved may very well determine the resolution of other dilemmas regarding accountability, confidentiality, the nature of the service offered and the scope of skills needed for the delivery of these services.

\section{Professional Orientation}

A perpetual issue within the social work profession in general has been the question of professional focus: should the focus be on the person, the environment, or both? This "cause-function" issue becomes especially crucial as social 
work practice enters the industrial environment. While there are those practitioners who maintain that the social worker's primary responsibility is the intrapsychic or psychological problems of clients, not union and corporate activities, there are others who argue that ignoring hazardous or dehumanizing conditions of the workplace when making assessments and interventions will minimize social work contributions in industry (Bakalinsky, 1980). This issue has been argued among social workers since the profession's inception, and continues to be a major point of debate within the field.

\section{Entrance}

Working in an industrial setting offers the social worker an opportunity to intervene in a complex system which has daily impacts on the population at large. Yet entrance into this system has proven to be difficult for a variety of reasons. The previous section pointed out some of the ideological barriers which have traditionally kept social workers out of industrial settings. Once a practitioner gains entrance into the system, there are still a number of problems that he/she must confront. One of the first issues that must be dealt with after entering the industrial setting is the actual location of the social worker (Akabas, 1979). If the social worker is to be employed on-site, he/she will probably be located in the medical and/or personnel department. Hence, the social worker may be located in a department which may not be accustomed to the role of a social worker. The social 
worker may be expected to assume some of the roles that other personnel assumed prior to the practitioner's arrival. The industrial social worker must understand that union representatives, nurses in the medical department, personnel staff and/or business agents may have, in some degree, carried out basic social work functions. Therefore, a social worker must form alliances with these individuals in order to minimize professional territorial issues. While these alliances are necessary to conduct effective social work, they do not prevent professional isolation, which sometimes occurs when the social worker is the only practitioner in the company.

It is common for the social worker to fear that the daily professional isolation may result in an erosion of his/ her ethical base, the foundation of the social work practice. This lack of interaction with other social workers makes it necessary for the practitioner to be secure with his/her professional identification. Without this personal security, the success of the social worker in an industrial setting may be limited.

Akabas (1979) has noted that when working within an industrial setting, one must not only maintain a high level of professionalism within the field of social work, but one must also broaden one's range of skills. Rather than being primarily a private counselor, many industrial social workers have found themselves to also be debt counselors, drug advisors and the major providers for information and referral. 
Thus, upon entrance into the industrial system, the social worker must cope with a variety of problems. The practitioner must immediately deal with the problem of location, the need for internal alliances, the potential of professional isolation, and the broad range of skills necessary for the wide range of employee problems. It is evident that the issue of entrance is only one of a variety of topics that must be discussed.

Social Control Versus Change

Once the social worker has successfully dealt with entrance issues, he/she must be prepared to confront the issue of social control versus social change (Akabas, 1978). For example, if the social worker is hired by the employer to maintain worker stability and reduce potential strain within the worksite, then the social worker may be acting as an agent of social control. It is possible, then, that the social work practitioner may respond to the needs of the company by promoting the status quo within the worksite, rather than respond to the stated problem of the worker who seeks services. On the other hand, the practitioner may view his/her role as that of advocate for worker's rights and demands, which could bring potential conflict between workers and management, as well as between practitioner and management. This conflict has added ramifications if the social work practitioner has been directly employed by management. Thus, the issue of social control versus social change has the 
potential for conflict between the practitioner and employer, practitioner and client, and perhaps within the practitioner him/herself.

Accountability

Accountability involves two intertwining concepts, that of who is the client and that of to whom is the social worker held accountable. Ideally, the social worker and sponsor, whether this be management, union, labor, or a combination, would have discussed this issue prior to the social worker entering the workplace, as it is imperative that they come to terms with this issue. Both practitioner and sponsor should agree that the client is the employee at the worksite. Traditionally, the social worker has been held accountable by both the client constituency and the management (Akabus, 1979). For example, accountability to management has thus far entailed some type of statistical reporting to the company. Basic statistical reports have not proven to be a controversial issue among social workers, as long as reporting focuses on work-related issues rather than psychological information. Kennecott Copper Corporation in Salt Lake City, Utah, has attempted to solve the accountability problem by utilizing broad goal statements for its social service department, i.e., reduced absenteeism and reduced medical and hospitalization rates (Skidmore, Balsam, and Jones, 1974). If there is a drop in absenteeism, then the program is assumed by the management to be fulfilling its goals. 
Confidentiality

Within the field of industrial social work, the issues of confidentiality and accountability are closely connected. Confidentiality is an especially sensitive issue within the industrial setting because a social worker's job security may be at risk if an employer has access to clinical files. In order to avoid this dilemma, social service programs should be clear in the manner in which workers are evaluated. If the company develops clear behavioral criteria for evaluation of the worker, for example, increased job performance, then the employer has no need for information regarding a consultation session between social worker and client. This method of evaluation is presently being used by Beth Israel Hospital in Boston. In this setting, early improvement in work performance and/or a clear indication that the worker is trying to overcome his/her difficulties creates an atmosphere in which confidentiality can be maintained as long as the individual chooses to seriously confront the existing problem (Leeman, 1974). Stone and Crowthers (1972) take a different stand on the issue of confidentiality and point out that open communication between the client, union stewards, and supervisors is important primarily because these individuals have worked together for a long time and may collaborate in solving the problem. Stone and Crowthers also stress that it is the responsibility of the client alone to decide whether to confide in the union steward and/or supervisor. The social 
worker may recommend this option to the client. However, the chosen course of action should evolve from individual problem evaluation and should maximize client confidentiality.

\section{Program Acceptance}

Stone and Crowthers (1972) cite that one of the foremost barriers to provision of services is the lack of acceptance of these services by some blue-collar families. Apathy, fear, suspicion, and misinformation often thwart the social worker from helping individuals within industry. Traditionally, social workers have worked with either the impoverished or the middle class; hence, the blue-collar worker and the social worker must collaborate to tear down the old barriers that have kept the two populations separate from one another.

The issues of value conflicts, professional orientation, social control versus social change, accountability, confidentiality, and program acceptance are six dilemmas which confront a majority of social workers at some point in their work activities, and therefore are not specific to industrial social work. Issues which are uniquely related to industrial social work involve the provision of services either on or off the worksite.

\section{On-Site Issues}

When a social worker is employed directly by a company, it is more than likely that the practitioner will be providing services at the workplace. Calvin Leeman (1974) suggests that 
providing on-site services may promote a higher potential for conflicts of interest to arise. For example, a social worker might counsel an activist worker to leave the company with which he/she is discontent, primarily for the benefit of the company. Or, if the social worker is employed within a company where the workers must spend several months in intensive training, an employer may not want to see an investment in the company's future leave the organization. Hence, the social worker may feel pressured to counsel the employee to remain within the organization. In short, it may be difficult to help employees reach decisions in their own best interest. This issue is closely related to the concept of client self-determination.

On-site service provision risks the social worker's being labeled via the informal, internal grapevine (Akabas, 1979). For example, if employees begin to notice workers with drug abuse problems visiting the social worker, that practitioner might erroneously be labeled as a drug counselor. To confront this problem, the practitioner might make $\mathrm{him} /$ herself more visible within the industry by walking around the plant and informally talking to the employees. This visibility could have dual side-effects. First, the social worker would become more familiar with the internal grapevine, and, secondly, he/she would also become more familiar with the work setting. This knowledge may enable the social worker to more accurately assess problems the 
employees face on a daily basis and in turn realistically develop rehabilitation plans for clients.

With the social service department located within the worksite itself, the social worker may be limited by company expectations to concentrate on the presenting problems of employees. Yet, in many ways, the worksite is a microcosm of the community at large, and in order to be a fully effective practitioner, it would be necessary for the social worker to become familiar with both the needs and resources of the local community. In so doing, the practitioner would be in a unique position of knowing the existing network of specialized resources in the community and could act as a broker by connecting employees to high quality specific services. It is this ability of linking individuals to services which enables the social work program in industry to branch out into the community.

Off-Site Issues

Sometimes social services are offered through the workplace but at a separate site, as when a community mental health center contracts with a company for services. In contrast to on-site programs, one of the major limitations to working off-site is employee accessibility to services. When off-site services are provided, the relationship between the client and the social worker may be more formal because the social worker is not part of what Weiner, et.al., call the "functional community" of the workplace. Moreover, 
the client would have to make a special trip to the agency in order to see the social worker, thereby minimizing the chance of "dropping-in" and casually talking to the social worker. Accessibility works both ways, in that the social worker does not have access to the informal grapevine. By working off-site, the social worker may have to make extra efforts to become familiar with the client's work environment.

There are a variety of advantages in maintaining distance between the worksite and the provision of services. Minimized conflicts of interest and the potential for more time allocated to community needs and resources were discussed earlier. In addition, Leeman argues that off-site contractual programs have the potential for offering quality service, in that a professional mental health organization is better equipped to recruit qualified social workers than are most businesses. Moreover, when the social worker is located in a social service agency, he/she would have immediate access to consultation from colleagues. This is in contrast to the social worker who practices on-site and who may periodically feel professionally isolated from peer support. In addition, some social workers believe that remaining off-site can increase the level of confidentiality, in that while a social worker may be under contract to and held accountable by a particular industry, he/she would be employed by a separate, neutral agency (Leeman, 1974). 
Existing research of actual social services provided at or through the workplace will be presented. The following section will explore the various types of programs and will discuss the results of such programs.

\section{EFFECTIVENESS}

Industrial social work has only recently become more commonplace, yet psychiatry has been active in the field of occupational mental health since the turn of the century. In 1915, the Cheney Silk Company was the first industry to employ a psychiatrist on a full-time basis (McLean, 1966). Many large corporations soon followed suit. The greatest stimulus to the study of industry as a social organization came in 1927 with the classic Hawthorne experiments at Western Electric. These studies demonstrated that "dissatisfactions arising in or out of the plant become entwined, influencing each other and affecting work production" (McLean, 1966, p. 963).

Alcohol rehabilitation programs were one of the earliest attempts to deal with employee problems affecting the work environment. Industries such as American Airlines, General Motors, Eastman Kodak, and New York Transit Authority are some major organizations which have offered alcohol programs to its employees (Holden, 1973). These programs were often staffed by recovered alcoholics, who usually had limited expertise in the diagnosis and treatment of other 
problem areas. The shift in clinical emphasis to broader areas of activities such as group process, mental health education, and program development was instrumental in catching the interest of the social work profession. Many industrial social workers began in alcohol programs. Among professional workers, there is no general agreement about what constitutes alcohol abuse. However, commerce and industry use a simple definition, which relates soley to the individual's role as worker. This definition is based on job behavior and is measured by such factors as quality of performance and number of absences from the job (Heyman, 1971). In an experiment in ontario, Canada, community industries referred alcoholic employees to the Industrial Unit of the Addiction Research Foundation, a multi-disciplinary inpatient facility offering comprehensive services over an average of three or four weeks. After the first year of operations, the facility claimed an unofficial success rate of 85 percent (Heyman, 1971).

The aforementioned INSIGHT program of the Kennecott Copper Corporation, a large mining company in Salt Lake City, was originally designed as a recovery program for employees having alcohol problems. In some categories, the program reduced absenteeism by 44 percent (Skidmore, Balsam, and Jones, 1974). Because of the program's success rate with alcoholism, Kennecott expanded its project to include all types of absenteeism. In 45 months, 5,500 employees and 
their dependents utilized the services, some more than once. The main problems, in descending order of frequency, were family, alcohol, the law, marriage, finance, and drug abuse.

The concept of the EAP emerged from these attempts during the last 30 years to establish alcohol rehabilitation programs in some industries.

One of the pioneers and prototypes of EAP's was a trial project originated by Xerox Corporation of Rochester, New York, in collaboration with Family Services of Rochester. Xerox purchased 32 hours of service per week from the agency, whose designated staff member focused on family and personal problems which jeopardized employment. One of the unanticipated results indicated that 44 percent of minority employees were served at the company, as opposed to 12 percent minorities served at the agency. Due to the high rate of minority employees who apparently needed services of one kind or another, Affirmative Action assumed ongoing funding for the project once the initial funding was depleted. Another early EAP was developed by Weiner, Akabas, and Sommer (1973), and took place in the men's and boy's clothing industry in New York City between 1964 and 1968. The issue was "how to bring mental health services to a population which...is under-cared for, under treated, and at the same time is an under-utilizer of care" (weiner, et. al., 1973, p. 15). The work was done as part of a cooperative program between a mental health project and union and 
management representatives of the factory. The frame of reference for the project stemmed from four specific questions:

1) How can one locate people in the world of work who are suffering from emotional problems? 2) How does one engage and sustain the involvement of blue-collar workers in the treatment process? 3) What is the nature of treatment and how is it influenced by being provided within the world of work? 4) What should be the division of labor among patient, clinician, "significant representatives" in the world of work and community agencies? (Weiner, et. al., p. 144)

In answering the above questions, weiner and colleagues concluded that locating mentally-ill workers is dependent on the degree to which seeking help is legitimized by union and management, the degree to which the helping professional is visible, and the degree to which the service is perceived as adequate. With respect to engagement, involvement was facilitated with the assistance of a trusted person and was sustained as long as workers were not identified as psychiatric patients. Treatment was aimed at functional performance and emphasized work behavior. Essentially, the professional's role was often that of mediator, in helping the individual negotiate the work system. The division of labor was shared among the resources within the industrial network, the community at large, and the professional helper, thus encouraging participation of many resources and expanding the roles of everyone involved, including the patient. Weissman (1976) refers to industrial social services as linkage technology," since emphasis is on locating specific 
resources with services directly related to the specific problem.

Since the Weiner, et. al., project, a number of innovative social service programs have been developed for industrial families, one of which was the aforementioned U. S. Steel Corporation of Chicago. The intervention model used here was a modified version of Reid and Epstein's Task-Centered Casework Model, where the focal construct was the "expressed, considered request" a person made about the problem with which he/she needed help (Reid and Epstein, 1972, p. 35). In its first eight months of operations, 661 employees and 267 family members were served; the most frequent types of problems brought to the Center were socio-environmental and financial ones. In addition to traditional problems encountered by social workers, the practitioners at U. S. Steel also became experts in such diverse areas as bankruptcy proceedings, wage assignments, consumer fraud, and legal problems of all kinds (Weissman, 1976).

In Michigan, a public mental health clinic joined with the United Auto Workers to provide services to employees and families of major automobile manufacturing firms (Stone and Crowthers, 1972). Funds for these services were available through Blue Cross and Blue Shield insurance benefits up to $\$ 400$ per year per family member. Provision of services was off-site at the clinic, with special evening and weekend hours to accommodate the varied employee shifts. Despite 
the difficulty in gaining acceptance by blue-collar families, the clinic served 393 individuals at the end of the first year. Personal complaints and marital problems constituted the bulk of initial presenting problems.

As social work services in industrial settings have become more prevalent, a variety of approaches have been developed in the larger industrial areas. A family service agency which contracted to provide on-site services to olin Corporation, a conglomerate in New Haven, Connecticut, utilized two experienced second-year MSW students as part of its project staff (Brooks, 1975). While this approach has its limitations due to the yearly turnover rate, it nevertheless provided additional staff at no additional cost to the agency. Another program, which was developed by a large private steel making company in Chicago, arranged for a community mental health psychologist to provide counseling consultation to untrained industrial counselors within the firm (Lepkin, 1975). These counselors were regular employees who had been selected by management for their knowledge of steel mill operations, not for their knowledge of counseling skills. The consultant's services were provided free by the clinic as a service to the community; hence, he had no "official" paid capacity within the company. While the project enjoyed limited success, it did not gain the support from foremen and supervisors, who were reluctant to refer to the counselors. Brooks (1975) and Stone and Crowthers (1972) also 
found that their respective programs depended greatly on referrals from foremen and supervisors, but these key people were often reluctant to refer employees for counseling for fear that management would interpret this as poor supervision.

In attempting to involve foremen and supervisors in the rehabilitation process, a counseling firm in Pennsylvania trained these middle-line management personnel to provide the services. This training proved to be successful. The CEMP Supervisory Training and Industrial Mental Health Program's target training areas were three-fold: 1) basic skills in human relations, communications, and crisis intervention, 2) constructive methods of problem-solving, and 3) effective information and referral (Bowler, 1980). The counseling firm chose the methods and procedures after a formalized needs analysis, which pointed to a lack of trust between upper management and the workforce, with foremen and supervisors often being caught in the cross-fire. It was believed that when first-line supervisors provided the mental health services, "the positive results accruing from such training would spread both downward to the general work force and upward to management" (Bowler, 1980, p. 91).

As was addressed earlier, yet is important to reiterate, a central dilemma common to most of the programs cited revolved around the question of "whose agent is the clinician?" Ideally, the clinician would serve labor, management, and 
worker. However, since the clinical staff is hired by management, they are understandably viewed by both supervisors and line workers as working for management, and as such, are not trusted (Stone and Crowthers, 1972; Weiner, et. al..' 1973; Lepkins, 1975; Brooks, 1975). Clear delineations between clinical staff and management are crucial in order to maintain allegiance-free associations within the company. Googins (1975) stresses the functional separateness between management, who monitor job performance and refer employees with job deficiencies, and treatment personnel, who diagnose problems and establish treatment plans.

Despite the number of programs cited in journals, little is really known as to the extent and kinds of services offered at or through the worksite. In a study prepared for the Manpower Administration, Hans Spiegel (1974) examined 23 worksites in the New Jersey-Westchester County target area, and surveyed "deliberately planned endeavors" to provide nonwork-related services at or through the workplace. Spiegel defined services as

..organized activities at or through the workplace whose primary intent, focus, thrust, or direction does not point towards the on-the-job productive capacity of the person-as-employee, but towards the off-the-job roles of the employee-as-person ..." (Spiegel, 1974, p. 10)

The survey located 615 different instances of specific services available to employees. These services were classified into eight categories: recreation and entertainment, community services, workplace amenities, self-actualization, 
individual and family assistance, education, information and exchange, and non-work-related economic enhancement. While Spiegel made a number of specific recommendations based on his findings, his over-all conclusion was that:

...the workplace is an under-utilized and potentially potent point for the discharge of services; if more than token services are to be made available at the workplace, employees themselves must participate actively in the planning and conduct of carefully designed and adequately funded service programs (Spiegel, 1974, p. 31).

\section{SUMMARY}

Society's attitude about work and its workers seems to have come full circle since the feudal system of the Middle Ages. Under feudalism, a liege lord protected his serfs against economic, political, and social disaster in exchange for their labor on his land (de Schweinitz, 1975). With the shift from feudalism to a capitalistic democratic society and wages as the medium of exchange for labor, work became symbolic of a person's worth. Contemporary American society continues to view a person's worthiness by his/her paid work activity, and stratifies these activities on a tightlystructured hierarchy from most-valued to least-valued. As a result of this, psychological and sociological aspects of work directly affect the manner in which most Americans conduct their working lives.

During the past decade, changing trends in the American labor market and workers' rising expectations of the workplace 
have resulted in an increase in worker alienation from the worksite and, frequently, decreased productivity. Organizational concern about production and employee stability and social work's traditional concern about the individual's relationship with his/her environment created the emergence of a new arena for social work practice.

The historical relationship between social work and industry had its roots in industry's early attempts to ward off union infiltration into the workplace by utilizing social workers as buffers, or trouble-shooters for work-related issues. Today, poor working conditions are defined less as unsafe physical conditions or deplorable wages, but more in terms of the lack of control over one's working conditions and the lack of opportunity to seek self-actualization and fulfillment. Employee benefit programs are being developed and implemented in many large business and industrial organizations, which are responding to employee demands that these organizations recognize the worker as a total person, not just as a means to company profit.

The entrance of social workers into the arena of industry raises certain significant issues, not all of which are specific to industrial social work. Of critical importance is the inherent conflict between social work's emphasis on people and industry's concern with profit. Also, how a social work practitioner resolves the traditional, chronic issue of cause versus function, that is, is treatment geared 
towards the individual or the cause? - seems especially relevant within the context of industrial social work. An issue unique to the field is one of sponsorship. The differing patterns of sponsorship greatly affect other issues of entrance, accountability, confidentiality, the nature of the service, and whether workers are best served onsite or offsite.

A survey of employee social service programs in the United States indicates a variety of approaches to help the worker within the industrial setting. Sponsorships differ in format among that of management, both management and labor, private consultantship, and contractual arrangements with an outside social service agency. Each approach has its advantages and limitations. These programs have enjoyed varying degrees of success, a factor which was often dependent upon the cooperation and understanding of supervisors and foremen. Workers who have utilized these programs have presented typical problems of people leading normal lives, and social workers have had to become experts in non-traditional areas of practice in order to effectively serve the target population.

It seems apparent from the literature that the workplace is beginning to take a more compassionate view of its workers, a view motivated either by self-interest or by a humanistic interest. Regardless of motivation, what is emerging is the development of what Akabas and Weiner (1974) call mutual aid 
networks, of which the employee social service program is one aspect. Gilbert and Specht also regard mutual support functions as essential, and "...come into play when individuals are not able to meet their needs through the major institutions which operate to carry out...other social functions..." (1974, p. 5). In this respect, the American workplace seems to be approaching amazing similarity to the paternalistic system of Middle Age European feudalism. 
CHAPTER III

METHODOLOGY

INTRODUCTION

This research endeavor was undertaken in order to address the question: "What non-work-related services are available to employees in worksites in the Tri-County area of Clackamas, Multnomah, and Washington Counties in Oregon?" The definition of non-work-related services, derived from a similar study done by Hans B. C. Spiegel and colleagues, is:

...organized activities at or through the workplace whose primary intent, focus, thrust or direction does not point towards the on-the-job production capacity of the person-as-employee, but towards the off-the-job role of the employee-as-person. (Spiegel, 1974, p. 10)

The research team had six months in which to produce and pre-test a questionnaire, conduct interviews, and interpret the findings.

The Spiegel Study

This exploratory research project, directed by Hans B. C. Spiegel, was conducted under the auspices of the Urban Research Center at Hunter College of the City University of New York and the United States Department of Labor. The results of the study were published in 1974. During the year-long study, 125 interviews were conducted at 23 worksites. 
The worksites chosen by Spiegel were located in the eastern United States and were chosen to meet several criteria. These criteria included: (I) both union and nonunion worksites; (2) small, medium, or large worksites with a fairly equal representation from each size; (3) worksites in the business of producing goods or providing services; and (4) worksites with a reputation for service.

\section{THE TRI-COUNTY STUDY}

Worksites in the Tri-County Area

The Tri-County area has diversified industry. This includes manufacturing, lumbering and wood products, and agriculture. Size of businesses vary from those employing over 3,000 people to those which employ one person.

In Multnomah County the major private-for-profit industries are represented by manufacturing, transportation, wholesale and retail trade and tourism. There are approximately 7,100 such businesses employing 145,000 people. Multnomah County has 1,550 agencies providing education, health, and social services. Approximately 25,400 people are employed in these agencies. This County has 160 governmental agencies employing 54,000 persons.

Clackamas County has approximately 470 private forprofit industries employing 12,500 people. This industry is centered on lumbering, manufacturing, agriculture, and warehousing. Clackamas County has approximately 300 agencies 
providing education, health, and social services. Approximately 4,400 persons are employed in these agencies. The County has approximately 120 governmental agencies which employ 12,000 persons.

Washington County's private-for-profit industry is largely in agriculture, lumbering, manufacturing, food processing and electronics. This includes approximately 470 businesses employing 25,600 persons. Education, health, and social services are provided by approximately 400 agencies employing 5,700 people. The County has approximately 80 governmental agencies which employ 9,600 persons.

As can be seen, Multnomah County has the largest business and industry and employs the most people. Within all three counties most people are employed by private-for-profit businesses. The second largest employer is government organizations. Health, education, and social service organizations employ the fewest number of employees. No data is available on the nonprofit organizations as a separate unit (State of Oregon Employment Division, 1977).

\section{Sampling Procedures}

The research team did not randomly select the worksites to be studied. Instead, worksites that met the parameters of the spiegel criteria were found through library searches, discussions with people in the community and at Portland State University. The personal knowledge of team members who were familiar with the Tri-County area was also considered 
in the selection of worksites. Sixty worksites were selected and were divided into five categories: (1) nonprofit corporations, (2) private-for-profit organizations, (3) governmental organizations, (4) education organizations, and (5) representatives of the social services. Within each category the research team tried to maintain an even mix of small (less than 250 employees), medium (251 to 1,000 employees), and large (over 1,001 employees) worksites. It was not possible to obtain an even distribution by size among the different worksite categories because of the nature of the businesses in the Tri-County area. Worksites tended to fall in the small category. No attempt was made to obtain an even mix of union and non-union worksites nor to select worksites that had an established reputation for service, as there were too few sites that met these criteria.

The Sample

Sixty worksites were chosen to participate in the study. Fifty-two of these participated in the interviewing process. Twenty-six of the participating worksites had union representation. There were 32 (62 percent) small, nine (17 percent) medium, and 11 (21 percent) large worksites. This includes 11 (21 percent) nonprofit corporations, six (12 percent) private-for-profit, 12 (23 percent) governmental, 12 (23 percent) educational, and 11 (2l percent) social service organizations. 
Interviewees

At each worksite, the research team attempted to interview two employees, one management level and one nonmanagement level. If the employees were represented by one or more unions, a shop steward was interviewed. The purpose of conducting up to three interviews at each worksite was to insure that adequate information was gathered. It seemed possible that just one person might not be aware of all services available.

Initially, the research team expected to randomly select the nonmanagement level interviewee from the employee roster. However, since the interview required over an hour to complete, the research team concluded that management could best determine which persons could be released from their duties for this length of time. Therefore, all nonmanagement level interviewees were selected by management. The research team noted that since this was an exploratory study and the sample size was small, randomization was not essential to the study.

Matching Interviewers and Worksites

There were 12 research team members. In order to determine which team member would visit each worksite, worksites were assigned numbers by a three-member committee. Each worksite was then grouped by number, according to the city or county in which it was located. Cities represented 
included: Oregon City, Milwaukie, Beaverton, Hillsboro, Aloha, Estacada, Forest Grove, Canby, Molina, Wilsonville, Tualatin, and Portland. The City of Portland was further divided into five areas: downtown, southeast, northeast, southwest, and northwest. Each researcher chose five sites by location and number and was then given the name and address of the worksite and the name of a person to contact for permission to conduct the interviews. This contact person was usually a manager or personnel officer at the worksite. In one case, a research team member had to reject a designated site because of a personal relationship with that site. This team member selected another site. The first site was placed back on the list again to be selected by someone else. Interviews took place between November 20, 1980, and January 9, 1981 .

\section{THE INTERVIEW SCHEDULE}

The interview schedule was developed by a three-person committee within a period of one month. All those involved in the research project periodically offered criticisms and suggestions to this committee.

As a general guideline, the committee used some lead questions implicit in the spiegel study, plus a rather sketchy questionnaire consisting of 14 open-ended questions provided by Spiegel. Because the nature of the study was somewhat different from Spiegel's and because the research team needed 
quantifiable data in order to effectively utilize the information received, Speigel's questionnaire was revised.

The purpose of the interview schedule was to determine what non-work related services exist in the selected worksites in the Tri-County area. From this purpose the committee developed questions about the history of services, attitudes towards the services, evaluation of services, organization of services, resistance to services, what services were not being provided, and the community orientation of the worksites. In addition to the main goal of surveying existing services, the research team was interested in providing enough baseline data to be useful in guiding future research. Hence, a rather extensive interview schedule was finally approved. (See Appendix D.)

Construction of the Interview Schedule

In order to refine and clarify the interview schedule and its application, a three-hour workshop was given by Robert Holloway, an Assistant Professor of Social Work at Portland State University and an expert in research methodology. A number of issues were addressed at this workshop. It was necessary to focus the interview schedule to assure that the primary goal of surveying existing services was met. As a result, the questionnaire was expanded to include short definitions and examples of services. Extra space was allotted for unsolicited responses. Questions were revised to insure that only one concept was addressed per 
question. A number of questions were revised so that interval and ordinal, as well as nominal data, could be collected. Holloway also discussed two points relating specifically to the administration of the questionnaire. One of these was that a solid understanding of the concepts behind the questions was needed by all research team members in order to assure reliability. The other point made was that as social work students, the research team members had a fairly high level of interpersonal skills to help elicit high quality information.

The interview schedule was ordered in a logical and purposeful sequence. The eight categories of services developed from the Spiegel study were listed and defined. Interviewees were expected to list services under each category. These categories and abbreviated definitions are as follows:

Recreation and Entertainment: Any type of recreation or entertainment for the workers and/ or their families, on or off the worksite.

Education: The worker and/or his/her family gets encouragement or money to further his/her education. This can be through classes given on or off the worksite.

Community Service: Anything that helps out the community or certain institutions. These activities can be started by the company, the employees or people in the community.

Information and Exchange: The way workers find out about things (activities) that are going on at the worksite.

Workplace Amenities: Any facility at the jobsite that helps the worker with non-work-related 
activities. These can be for things like the workers' relaxation, group meetings, or other things. They may be free to the worker or at a cheaper rate. These may be offered to the worker alone or his/her family, or even to the community. This also includes services provided from one worker to another.

Self-Actualization: Activities that help a person feel better about him/herself, help express creativity, or become aware of the needs of others.

Individual and Family Assistance: Services to help workers and their families deal with health, money, personal, and psychological needs. These needs are not directly related to work. Services that help prevent a problem or get rid of it once it occurs.

Non-Work-Related Economic Enhancement: Activities that help the worker to manage and/or save his/her money. (See Appendix C.)

The next part of the interview schedule contained questions which concerned the history of the services, the evaluation of services, and attitudes of employees toward the services. Other questions asked whether or not the worksite could be used more systematically in providing assistance to the employees, what types of assistance might be appropriate at the worksite, and the worksite's orientation to the community (the worksite's awareness of the problems and needs in the community).

The final section, directed only to managers, garnered demographic data about the worksite. Some of this data included numbers of employees, turnover rate, wage distribution, and male/female ratios. 
COLLECTION OF THE DATA

Contact with Worksites

Each member of the research team initiated contact with five worksites. A letter introducing the purpose of the research was sent to a manager or personnel officer at the worksite. (See Appendix B.) This letter requested interviews with at least two persons. It also assured the interviewees and the worksites of confidentiality. A phone call was subsequently made to answer any questions that the manager might have regarding the nature of the research. This call also confirmed a time and date for each interview. The manager was informed that each interview was expected to take approximately one hour to complete and that the research included gathering general information on the nature of the worksite and composition of the work force.

At this stage in the process of securing interviews, the research team met with resistance on the part of management at some worksites. This resistance included both outright refusal to participate in the research or reluctance to participate. Reluctance to participate was inferred when the interviewer called repeatedly for an interview which was never granted. One worksite agreed to be interviewed, but was available only after the deadine for data collection had passed. Another worksite was eliminated by the research team because the management expected to use the research 
data to promote the worksite's public relations program. The research team concluded that this attitude toward the interview might skew the data.

Besides those worksites that were omitted from the sample for reasons of resistance, there were two worksites that were excluded due to an error in their selection for the study. The research team found that one worksite was a satellite agency of a worksite that was already interviewed by a member of the research team. At a second worksite, the management level employees were located out of state. Consequently, a total of eight selected worksites did not participate in the study.

TABLE I

REASONS FOR THE ELIMINATION OF SELECTED WORKSITES

\begin{tabular}{|c|c|c|}
\hline Reason & Number & Percentage \\
\hline Outright refusal to participate.... & 2 & 3 \\
\hline $\begin{array}{l}\text { Reluctance to participate (two or } \\
\text { more contacts made) ............... }\end{array}$ & 2 & 3 \\
\hline 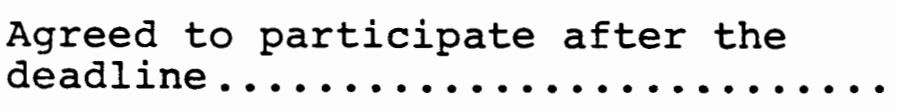 & 1 & 2 \\
\hline 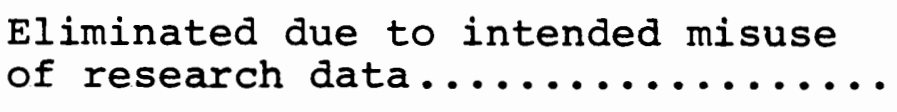 & 1 & 2 \\
\hline 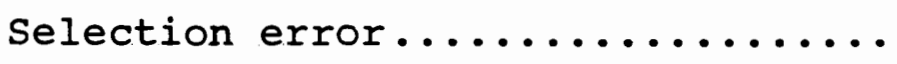 & 2 & 3 \\
\hline 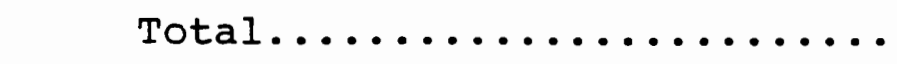 & 8 & 13 \\
\hline
\end{tabular}


Those worksites that did not participate in the study totaled eight, or 13 percent of the sample. The participation of 87 percent was excellent and exceeded the expectations of the research team.

\section{INTERVIEWING}

The interviewer was expected to pursue the interviews within each worksite until a clear and definite positive response was obtained or until a negative response from a worksite has been pursued for at least two contacts beyond the original letter and phone call. In the event of partial cooperation on the part of management, i.e., when the request to interview either a nonmanagement employee or a union employee (or both) was refused, the interviewer gathered whatever information was available. The research team agreed that some information (from the management level only at a worksite) was better than no information.

Having obtained at least one interview within a worksite, the interviewer arrived onsite with an interview packet consisting of the following items: consent forms for each interviewee (which fulfilled the requirements of the Human Subjects Committee of Portland State University (See Appendix B), a statement of purpose, explanation, and assurance of confidentiality, the interview schedule, and a face sheet for the collection of detailed cata on the worksite and workforce. This face sheet information was gathered from the management level interviewee. 
Each interviewer began the interview with a brief statement of purpose and overview which was designed to acquaint the interviewee with the concept of non-work-related services. Questions and concerns raised by the interviewee were handled at this time. When the interviewee indicated a readiness to proceed with the interview, the interviewer requested that the consent form be signed.

To begin the interview, the interviewer introduced the eight service categories of non-work-related services. The interviewer was instructed to listen to each service category definition and examples. Next, the interviewee brainstormed for those activities in each service area provided at the worksite. The researcher encouraged the interviewee to present as many examples of services as possible and focused the interviewee on the concept of non-work-related services. Issues such as the difference between a fringe benefit and services were discussed at this time, as well as specifics about whether a service could be considered "non-work related." Some researchers found that interviewees had difficulty distinguishing between work related and non-workrelated services. When the interviewee was unable to differentiate between the two, the interviewer discarded those stated services which did not fit the criteria of non-workrelated services.

Because of the nature of some services available at the workplace, there were occasionally questions about which 
category to use for a particular service. Interviewees might, for example, place a swimming pool under either "Recreation and Entertainment" or "Workplace Amenities." Interviewers were permitted to use their own discretion in properly placing the service because of their familiarity with the service categories.

When the interviewee had listed the services available at the worksite in each of the eight categories, the interviewer returned to the first service category. The interviewee was then asked to furnish detailed information for each service listed. This information included the financing of the service, the utilization of the service, and the reason for its initiation. This procedure was followed for each service in each of the categories.

The next section of the interview required the interviewee to consider services he/she would like to see implemented at the worksite. The interviewer explored with the interviewee the barriers to initiating and providing services at that worksite. Finally, the interviewer discussed with the respondent his/her impression of the worksite's relationship to the surrounding community.

At the conclusion of the interview, the interviewee was told that the research team would send a summary of the results of the study to the worksite. In the case of an interview with a manager, the face sheet information was gathered at this point. Occasionally, because of the length of the 
interview, the face sheet was left with the manager to complete at his/her convenience and return to the research team.

\section{CODING}

A three-member committee prepared a code book and coded those questions on the questionnaire that the research team decided to study. In coding and analyzing the data, the research team remained focused on the primary purpose of this study and the research question. In order to assure accuracy in the coding process, the committee members randomly selected questionnaires to exchange and recode.

A great deal of information was obtained from the questionnaires. However, the research team determined that not all of the information related directly to the research question. For this reason, some questions were not retained for coding. In this process, Questions ID and IG-IJ were eliminated from the analysis. The remainder of the questionnaire contained information pertinent to the research question.

In some cases there were not enough responses to provide a large enough sample size for adequate statistical analysis. This was true of several questions on the face sheet, including the request for racial composition of the workforce, salary information, educational level of employees and the distance employees lived from work. These items were subsequently omitted from the analysis. Information retained from 
the face sheet included union representation, the type of worksite, the size of the workforce, the ratio of males to females, and the employee turnover rate.

The level of community involvement and awareness of community problems was ascertained by combining questions XIIIA, XIIIB, XIIID. Community involvement was ranked on a scale of low to high, depending upon points gained in response to the questions. One point was given for each problem identified, two points for each problem the workplace itself addressed, and three points if the workplace coordinated with other community organizations in solving the identified problems. A low level of community involvement resulted in a score of 0-15, medium 16-30, and a high level of involvement at 31 and above. The mean number of responses from each worksite was used in order to control for differences that would have occurred due to having the responses of only one employee.

The research team obtained between one and three interviews at each worksite. In order to aggregate all non-workrelated services, the responses within each worksite were reviewed by the coders so that a single list of unduplicated services per worksite was acquired. This single list of services was then coded for each worksite which maintained the sample size of 52 .

For the analysis of other types of data, only the management responses were coded. This was done for two reasons. 
First, each of the 52 worksites permitted an interview at the management level, whereas nonmanagement and union respondents were not as consistently represented. Second, when more than one interview was procured at a worksite, responses to the same question were frequently contradictory. For example, to question IF, "Who pays for this service?," respondents at the same worksite reported different means of payment. Therefore, one response per worksite, that of the management level interviewee, was retained for coding.

The research team recognizes the bias inherent in this coding process. However, the primary focus of the research was to determine what services are available within a worksite rather than to analyze differing perceptions of service characteristics within a worksite. For this reason, the coding process preserves the research purpose.

The interviewing process included the collection of unsolicited responses from the interviewees. These were reviewed and categorized by members of the research team to discover common trends or concerns. These comments are included in the analysis when appropriate.

\section{RELIABILITY AND VALIDITY}

Generally, reliability is the consistency of a test, including the consistency with which the same measurement is obtained after an interval of time. Generally, validity is the capacity of a measuring instrument to predict what it 
is designed to predict. It is possible to have a reliable test which is not valid; but if a test is valid, it must be reliabile (Selltiz, et. al., 1976, pp. 580-581). Therefore, we are considering in this discussion validity and reliability simultaneously.

Reliability and validity in a research project can be discussed in at least two ways. This can be done in terms of reliability and validity of the instrument and in terms of reliability and validity of the process.

Since the research team used a nonstandardized multidimensional, multi-faceted questionnaire which was not sufficiently pre-tested, the validity and reliability of the instrument cannot be determined. The instrument does have face validity in that it appears to be properly designed and appropriate to the research question (Selltiz, et. al., 1976, p. 577) .

However, an analysis of the reliability and validity in terms of process is possible. It is known that when several persons deliver questionnaires, differing delivery styles can influence the reliability of the process. Due to the fact that there were 12 individuals administering this questionnaire, a potentially adverse affect on reliability existed. Realizing this, the research team attempted to control for this problem by participating in an interviewer training session. This certainly did increase the reliability of the process. 
A factor that can affect the validity of the process is the degree of compliance with the plan of action. The research team developed steps that would be taken to complete this study, including initial contact with worksites, the interviews themselves, and follow-up procedures. In that there was compliance with these steps on the part of the interviewers, the validity of the process was increased. In that several worksites were lost and this factor decreased compliance with the plan, validity suffered.

Another factor adversely affecting the validity and reliability of the process was fatigue resulting from the length of the questionnaire. Fatigue affected both interviewers and interviewees and resulted in some inconsistent responses near the end of the interview.

Finally, a learning factor had an influence upon the manner in which interviews were delivered. Undoubtedly, interviewers delivered the last of the five questionnaires more skillfully than the first. This difference might decrease reliability and impact on the validity of the process.

Because of the limited resources with which the study was conducted, all issues regarding reliability and validity could not be controlled. However, the fact that training sessions were conducted for interviewers and a plan of action was developed and implemented, the validity and reliability of the process was enhanced. 


\section{STRENGTHS AND LIMITATIONS}

Strengths

This research effort is the first of its kind in the Tri-County area. The team's persistence in contacting the selected worksites resulted in an unusually high level of participation. While 60 worksites were contacted originally, 52 worksites were visited by a member of the research team. This compliance rate of 87 percent is outstanding and far greater than originally anticipated.

From the 52 worksites interviewed, researchers were able to interview more than one representative at 42 of the worksites. This enabled a composite picture of services to be constructed from differing viewpoints in the organization. This strengthens this research. It lends a credibility that might be lacking had the team interviewed only the management. As it stands, this research is enriched by having incorporated the viewpoints of management, labor, and union to the extent possible.

The interview, composed of both closed and open-ended questions, was designed to draw specific information and personal perceptions from the interviewees. Setting an environment conducive to exchange was an important element in conducting this interview. The interviewing skills of the research team members enhanced the interviewing situation. 


\section{Limitations}

Because of time constraints in conducting this extensive study in six months, a thorough pretest of the questionnaire was not conducted. Although the research team tested the interview schedule with friends and work acquaintances, this informal procedure failed to identify some of the flaws found later in the interview instrument. The research team found that several of the questions were imprecise. For example, question ID, "What was the reason this service was started?," seemed confusing to the respondent since the intent of the question was unclear. Most responded vaguely. Questions which were imprecise were subsequently eliminated from the data analysis.

A second consequence of the inadequacy of the pretest was the development of a somewhat long and cumbersome interview schedule. Many of the interviews went well over their allotted hour. This may have had an impact on the quality of the information received because of fatigue in both the interviewer and interviewee.

As discussed earlier, randomization of selected worksites and interviewees was not attempted. The worksites were chosen to reflect the uniqueness of the Tri-County area. This lack of sample randomization limits the statistical generalizability of the research findings to other worksites and work forces. While statistical comparisons in other 
geographical areas would be statistically invalid, comparative studies would be informative and useful.

\section{SUMMARY}

This exploratory study successfully answered the research question, "What non-work-related services are available at the worksites studied in the Tri-County area?" The research team obtained a high rate of participation from worksites invited to participate in the study. The data gathered from the interviews indicate what services are currently offered at the worksites studied as well as what services employees would like implemented.

The research team obtained an extensive amount of information about the worksites and non-work-related services. This information provides baseline data from which further research can be developed.

In the following chapter, research findings and analyses are presented. The analyses consider the relationship between worksite characteristics and the types of services provided. 


\section{CHAPTER IV}

\section{FINDINGS AND ANALYSIS}

This chapter presents and analyzes data collected from employees at selected worksites in the Tri-County area. First, characteristics of the participating worksites are reviewed. Second, data on the non-work-related services at the sampled worksites are presented and analyzed. Third, relationships between worksite characteristics and available non-work-related services are reviewed. As appropriate, results are displayed in tables by number, percentage, and mean value of the collected data.

\section{INTRODUCTION}

\section{Sample Size}

As mentioned in Chapter III, a maximum of three interviews was requested of each of the 60 worksites, totaling a potential of 180 interviews. The interview participation rate was 111 (62 percent). Eight worksites did not participate in the survey, and not all 60 worksites were unionaffiliated. There were 52 participating worksites. Twentysix (50 percent) of those worksites were union-affiliated, thereby totaling a potential of 78 interviews. The remaining 26 (50 percent) nonunionized worksites totaled 52 
potential interviews. Given that the actual number of potential interviews for the 52 participating worksites was 130, the 111 interviews achieved a participation rate of 85 percent. Of these 111 interviews, 52 (47 percent) were management, 42 (38 percent) were workers, and 17 (15 percent) were union representatives. In ten of the 52 worksites, management only was interviewed. Of these ten, one worksite employed only one person.

Worksite Characteristics

As described in Chapter III, worksites were selected on the basis of size and type. Of the 52 worksites, 11 (21 percent) were large, nine (17 percent) were medium, and 32 (62 percent) small. A total of 45,461 employees were represented by the 52 worksites.

\section{Number of Workers by Worksite Size}

Table II underscores the fact that the majority of worksites involved in this survey were in the small category. There are, however, a much larger total number of employees represented in the 11 large worksites. The non-random nature of worksite selection reduces the generalizability of the study. These 52 worksites and their breakdown by size are not necessarily representative of all worksites in the Tri-County area. 
TABLE II

NUMBER AND PERCENTAGE OF WORKERS ACCORDING TO WORKSITE SIZE

\begin{tabular}{r|c|c|c}
\hline \multicolumn{1}{c|}{ Size } & $\begin{array}{c}\text { Number of } \\
\text { Worksites }\end{array}$ & $\begin{array}{c}\text { Number of } \\
\text { Employees }\end{array}$ & Percentage \\
\hline Small...... & 32 & 2,412 & 5 \\
Medium..... & 9 & 5,311 & 12 \\
Large..... & 11 & 37,738 & 83 \\
\cline { 2 - 4 } Total.. & 52 & 45,461 & 100 \\
\hline
\end{tabular}

Participation Rate

In the survey, government and education organizations had the highest rate of compliance with all 12 (100 percent) participating. The next highest rate was 11 each (91 percent) for social service and nonprofit worksites. There are not statistically significant differences between the compliance rates for these four types of organizations.

The lowest rate of compliance was for private-forprofit organizations. Of the 12 worksites originally selected for this survey, only six (50 percent) participated. Though the difference is not statistically significant, some reasons why this occurred can be discussed. 
TABLE III

NUMBER AND PERCENTAGE OF WORKSITES, IN RANK ORDER, ACCORDING TO TYPE

\begin{tabular}{|c|c|c|}
\hline Type of Worksite & Number of Worksites & Percentage \\
\hline Government........ & 12 & 23 \\
\hline Education.......... & 12 & 23 \\
\hline 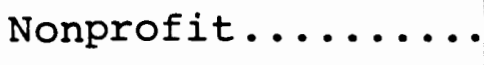 & 11 & 21 \\
\hline Social Service.... & 11 & 21 \\
\hline Private-for-Profit. & 6 & 12 \\
\hline Total......... & 52 & 100 \\
\hline
\end{tabular}

This survey was done under the auspices of the School of Social Work at Portland State University. Portland State is a public university and as such it is both an educational and quasi-governmental organization, in that it receives state funds. There may be some interest in cooperation between similar organizations, which could account for the high compliance rate in these two categories. Educational organizations may also share an interest in research and research hypothesis. Governmental organizations, on the other hand, may also want to create a positive public relations position. 
Social service organizations also had a very high compliance rate as did nonprofit organizations. For social service agencies there are two factors that may be involved. The first is that these agencies are often interested in the participation of social science research. That interest may have encouraged their participation. The second factor is that the School of Social Work has a good relationship with many of the social service agencies in the community. This positive relationship may increase the interest in cooperation.

Nonprofit organizations were equal to social service in compliance rate. One factor involved is that the majority (90 percent) of nonprofit organizations in the study were small, and the highest participation by worksite size were small worksites. Also, nonprofit organizations are in most cases dependent on the community for their support. This factor may have influenced their decision to participate. The most interesting category for this analysis is the private-for-profit organizations. Of the 12 selected sites, only six (50 percent) chose to participate in the study. There are several items that need to be addressed. Private-for-profit organizations did not stand to benefit in the same way that the organizations in the other categories may have. Their interest in social science research may be limited. There may also be minimal interest in cooperating with other agencies as this cooperation will not 
necessarily be to their benefit. The fact that these organizations are profit oriented may have influenced their decision.

Another interesting fact is that the six private organizations that did participate had a high average number of services. It is possible that their participation may in some way be related to their interest in public relations. It is only speculation at this point, but the six private organizations that did not participate may have had a low level of service provision. This argument may be supported by the fact that in four of the six private-for-profit organizations which did not participate, resistance was cited as the major factor.

It must be emphasized that it is not possible to do an in-depth analysis as to why a particular organization chose not to participate in this survey. It can only be pointed out that the combination of factors cited above may have contributed to the lack of interest in participation among private organizations.

\section{TURNOVER RATES, COMMUNITY INVOLVEMENT, AND FEMALE REPRESENTATION}

There were a number of variables collected in the study which were not analyzed. Three of these variables, turnover rate, community involvement, and female representation, while not statistically significant, deserve some comments. 
Turnover Rate

Employee turnover rates were reported by 37 (71 percent) of the worksites. The average turnover rate for these worksites is 18 percent, with a range of zero to 80 percent. The total number of employees represented by this turnover rate is not known.

There are some interesting points that need to be addressed concerning this variable. One worksite had an 80 percent turnover and three had a 50 percent turnover.

The data showed that all of these worksites were small, with three of them having fewer than nine employees. In organizations of this size, having one or two persons leave in a given year would dramatically affect the turnover percentage.

of the four worksites with high turnover rates, two of them had a higher than average number of services provided. Two of them had a low average number of services, but those two also had only four employees. This study does not support any relationship between turnover rate and service provision. In addition, two of the organizations were in the social service category and one in special education. A factor that might be explored in future research in this area is the impact of "worker burnout" on the turnover rate.

Community Involvement

Another area of interest was the level of community involvement of the various organizations involved in the study. 
Community involvement was ranked as low, medium, or high, depending on an assigned point basis as outlined in Chapter III. Thirty (58 percent) of the worksites demonstrated a low level of community involvement, 20 (38 percent) medium community involvement, and two ( 3 percent) high community involvement. Crosstabulations of this variable with relevant others were not done, but we can speculate as to why only two organizations considered themselves actively involved in solving community problems. One of these two is a private-for-profit organization and has a history and reputation for working with the community. The second is a nonprofit organization, and is dependent on its interaction with other organizations to solve community problems. Questions of confidentiality restrict further disclosure concerning these organizations.

Another issue needs to be addressed concerning community involvement. Of the 30 (57 percent) organizations listing a low level of community involvement, 17 (57 percent) are small. It seems likely that small organizations would not have the resources, the time, nor the personnel to be actively involved in solving community problems.

\section{Female Representation}

Based upon manager-estimated percentages of female/male representation at each worksite, women comprise approximately 47 percent of the employees in the sampled worksites. The actual total of females employed at the 52 worksites is not 
available. Again, the data in this category are not statistically significant. It was initially speculated that there may be a correlation between percentage of female employees and number and types of services provided. This survey does not support either of these speculations. At this point, no correlation between the above-described variables can be demonstrated.

\section{NUMBER OF SERVICES}

The survey located 1,189 unduplicated non-work-related services to the employees of the 52 worksites. (See Table IV). The following list is a complete description of those identified services.

Recreation and Entertainment:

Social activities

(organized celebrations, informal gatherings)

Athletic activities

(team, individual, unspecified)

special events

(spectator, tours, trips, retreats)

Hobby clubs

(arts/crafts, games)

Facilities

(access to or on site)

Education:

Specific training

(CPR/first aid, rape prevention)

Scholarship and tuition waiver

(degree focused - GED, bachelor, graduate, upward mobility) 
Education, cont.:

Sabbatical and educational leave 6

Field trips, tours 3

$\begin{array}{lr}\text { Community Service: } & 176\end{array}$

Educational $\quad 56$

(speakers' bureaus, instruction)

Work time for civic affairs

Use of facility for community activities 38

Financial assistance to community 16

$\begin{array}{ll}\text { Service to youth } & 12\end{array}$

Environmental activities 3

Information and Exchange: $\quad 159$

$\begin{array}{ll}\text { Publications } & 63\end{array}$

(newspapers, newsletters, memos)

Bulletin boards 59

$\begin{array}{ll}\text { Speakers, information sharing } & 27\end{array}$

$\begin{array}{ll}\text { Brochures and journals } & 10\end{array}$

$\begin{array}{ll}\text { Workplace Amenities: } & 258\end{array}$

Facilities at worksite 133

(lounges, lockers, showers, parking, lunchrooms)

Food service at worksite

(cafeterias, vending machines)

Utilization of company equipment

(phone, copy machine, vehicles)

$\begin{array}{ll}\text { Technical service provision } & 8\end{array}$

Self-Actualization: $\quad 85$

Self-fulfillment $\quad 56$

(skill building - emphasis to self)

Service to others at worksite 21

Service to others beyond worksite $\quad 8$ 
Health care services $\quad 44$

Treatment and referral services 41

(counseling, employee assistance plans)

$\begin{array}{ll}\text { Referral service only } & 17\end{array}$

Professional services 11

Flex hours, work hour benefits 3

Day Care I

$\begin{array}{ll}\text { Non-Work Related Economic Enhancement: } & 148\end{array}$

Commercial services $\quad 87$

(banking, credit union, investment options)

Discount services $\quad 45$

Gifts and bonuses 9

$\begin{array}{ll}\text { Financial counseling } & 7\end{array}$

The data displayed in Table IV is nearly identical to the Spiegel study. The only difference is that the spiegel data ranked Individual and Family Assistance as fourth and Information and Exchange sixth. This study reverses those two categories.

The four highest number of services are: (1) workplace amenities (vending machines, parking, lounges);

(2) recreation and entertainment (sports teams, clubs, parties); (3) community service (speakers, community use of company facilities); and (4) information and exchange (bulletin boards, lectures, films). All four high service categories represent relatively low cost services. The services 
in these four categories usually involve a one-time cost to the organization such as parking, cafeterias, bulletin boards, or vending machines. There is minimal ongoing maintenance costs for these services. Also, some of the cost is absorbed by the employees rather than the employer. This is true of sports teams, parties or vending machines.

\section{TABLE IV}

NUMBER AND PERCENTAGE OF UNDUPLICATED SERVICES, IN RANK ORDER, ACCORDING TO SERVICE CATEGORY

\begin{tabular}{|c|c|c|}
\hline Type of Service & Number of Services & Percentage \\
\hline Workplace Amenities..... & 221 & 19 \\
\hline 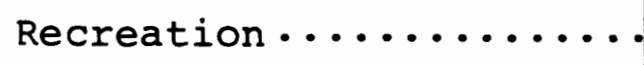 & 219 & 18 \\
\hline Community Service....... & 179 & 15 \\
\hline Information and Exchange. & 153 & 13 \\
\hline $\begin{array}{l}\text { Non-Work-Related Economic } \\
\text { Enhancement .......... }\end{array}$ & 120 & 10 \\
\hline $\begin{array}{l}\text { Individual and Family } \\
\text { Assistance } . . . . . .\end{array}$ & 113 & 10 \\
\hline Education $\ldots . . \ldots \ldots$ & 102 & 9 \\
\hline Self-Actualization ....... & 82 & 7 \\
\hline 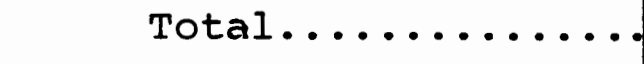 & 1,189 & $101 *$ \\
\hline
\end{tabular}

*Due to rounding the total percentage exceeds 100 percent. 
Financing may be the major factor; however, the services provided in these categories are also non-controversial services. Few would question their appropriateness for the worksite. These services appear to represent the minimal level of service provision in a worksite. All of these services can also be provided within the worksite. The four categories with the fewest number of services include: (1) non-work-related economic enhancement (banking services, discount tickets); (2) individual and family assistance (substance abuse treatment, counseling); (3) education (subsidies, scholarships, classes); and (4) self-actualization (group sessions, self-help groups). The services in these four categories involve continuing maintenance cost to the organizations. This is particularly evident in the categories of education and individual and family assistance. The financial question applies most often to small organizations. These worksites frequently lack the resources to provide these services.

Financial questions may not be the only consideration in providing these services. Fourteen of the respondents participating in the survey viewed the worksite as an inappropriate place for these services. As one of these respondents stated, "I don't think that services should be offered at the worksite. It is not appropriate. Work is not the place for it." Again, this may apply more frequently to small organizations than it does to large 
organizations. The services in the lowest four categories are more personal in nature and tend to be more controversial. There is also the question of the responsibility of the organization to provide services of a personal nature. For example, another of the managers interviewed stated, "Services at the worksite are inappropriate - it is paternalistic and assumes that the company knows best. Workers are adults and can find their own services."

The conclusions that can be drawn are that the majority of the services provided (65 percent) are low cost, non-controversial services. This conclusion is similar to one drawn by the spiegel study, that services represented "...relatively 'safe' and relatively simple services..." (Spiegel, 1974 , p. 76).

Number of Services by Category

The data in Table $\mathrm{V}$ is consistent with the data in Table IV and the same conclusions apply. The highest average number of services are in the categories of workplace amenities, recreation, community service, and information and exchange. As discussed earlier, these service categories include low cost, non-controversial services. This would account for the fact that the highest average number of services are in these four categories. 


\section{TABLE V}

\section{MEAN NUMBER OF SERVICES PER WORKSITE, IN RANK ORDER, ACCORDING TO SERVICE CATEGORY}

\begin{tabular}{|c|c|}
\hline Type of Service & Mean Number* \\
\hline 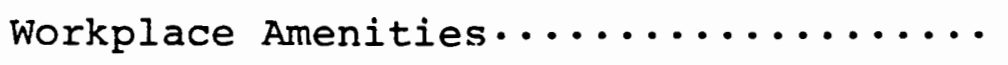 & 4.3 \\
\hline Recreation $\ldots \ldots \ldots \ldots \ldots \ldots \ldots$ & 4.2 \\
\hline 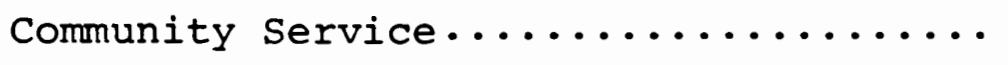 & 3.4 \\
\hline 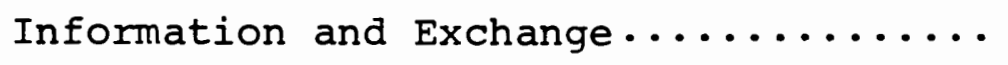 & 2.9 \\
\hline Non-Work-Related Economic Enhancement.. & 2.3 \\
\hline Individual and Family Assistance...... & 2.2 \\
\hline 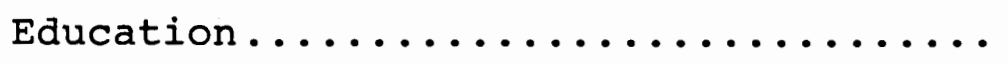 & 2.0 \\
\hline Self-Actualization............... & 1.6 \\
\hline
\end{tabular}

Note: Means scores pertain to the 52 worksites

\section{Barriers to Service}

Managers were asked to cite the barriers to initiating services at their workplace. Table VI represents their responses. Lack of money was the primary barrier to services, while labor disputes proved to be the least significant obstacle. 
TABLE VI

NUMBER AND PERCENTAGE OF BARRIERS IN INITIATING NON-WORK-RELATED SERVICES, IN RANK ORDER,

AS REPORTED BY 52 MANAGERS

\begin{tabular}{|c|c|c|}
\hline Barriers & Number of Responses & Percentage \\
\hline Lack of Money....... & 40 & 77 \\
\hline $\begin{array}{l}\text { Inappropriate for } \\
\text { Workplace........ }\end{array}$ & 15 & 29 \\
\hline $\begin{array}{c}\text { Lack of Staff In- } \\
\text { terest........... }\end{array}$ & 14 & 27 \\
\hline $\begin{array}{c}\text { Lack of Management } \\
\text { Interest......... }\end{array}$ & 14 & 27 \\
\hline Lack of Awareness... & 11 & 21 \\
\hline $\begin{array}{c}\text { Lack of Union In- } \\
\text { terest.......... }\end{array}$ & 8 & .15 \\
\hline 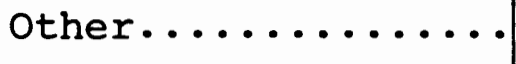 & 8 & 15 \\
\hline Lack of Expertise... & 7 & 14 \\
\hline Labor Disputes...... & 4 & 8 \\
\hline Don't know.......... & 1 & 2 \\
\hline Total..... & 122 & 235 \\
\hline
\end{tabular}

Note: Total percentage exceeds 100 percent because response categories were not mutually exclusive.

The table supports the discussion of the analysis of Tables IV and V. It should be noted that the categories are not mutually exclusive, which accounts for the fact that there are more responses than the total number of interviews. For example, an individual respondent might cite lack of interest, as well as finances, as the barriers to service provision. 
Another point needs to be made concerning this table. It applies to Tables VIII and IX as well. In tabulating the findings for these tables, only the management response was used. The rationale for this decision was that in ten (19 percent) of the worksites, only one person was interviewed. In these ten cases, the interviewee represented management. It was not the intention to eliminate union and employee responses nor to minimize their importance. However, in order to maintain the sample size of 52 in the analysis, it was necessary to analyze only management response.

Lack of money ranks highest in the barriers to services with 40 (77 percent) of the responses. However, it is important to note that lack of interest is divided into three separate categories: lack of interest of union, lack of interest of management, and lack of interest of employees. If these three groups were combined, the total number of responses would equal 36 , or 69 percent. This combination would rank lack of interest second rather than third, both in total numbers and in percentage. It must be pointed out again that the categories are not mutually exclusive. Labor disputes is another interesting category in this table. Only 50 percent of the participating worksites were represented by a union. Also, labor disputes are most of ten concerned with wages, hours, and fringe benefits. Concepts such as non-work-related services are rarely a consideration in these disputes. 
There is another difference to be addressed in this table. There appears to be a difference between subjective and objective responses to this category. Lack of money, expertise, and labor disputes are all objective concrete items and relatively easy to analyze. For example, either the money is available or it is not available.

The other categories are subjective and subsequently much more difficult to analyze. For example, lack of interest, lack of awareness, and inappropriateness all require a value judgement on the part of the respondent. There may be several factors that might influence a person's response to these categories. An analysis of these subjective responses would be difficult, if not impossible.

\section{Financing}

Lack of money was the major barrier to service provision as reflected in the discussion of Table VI. Another component of money needs to be addressed. The 52 managers were asked how the existing services were financed. The majority (66 percent) of the responses were that the services were financed by the employer. It is important to note that only managers responded to this question.

Statistical tests were not done on this question. This was due, in part, to the difficulty in computing the data and the fact that the responses may have favored the employer. Future research on this question might provide more information. 
Additional Services

Managers were asked to list a maximum of five services that they would like to have available through their workplace. The maximum number of services they might have identified is 260. They suggested 126 (48 percent). The number distribution of requests proposed by managers in each of the eight service categories is presented in Table VII.

TABLE VII

NUMBER AND PERCENTAGE OF DESIRED ADDITIONAL SERVICES, IN RANK ORDER, AS REPORTED BY 52 MANAGERS

\begin{tabular}{|c|c|c|}
\hline Category & Number of Services & Percentage \\
\hline $\begin{array}{l}\text { Individual and Family } \\
\text { Assistance } \ldots \ldots \ldots\end{array}$ & 29 & 23 \\
\hline 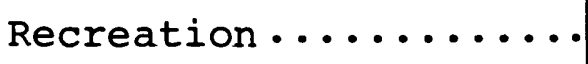 & 28. & 22 \\
\hline Education........ & 28 & 22 \\
\hline Workplace Amenities.... & 16 & 13 \\
\hline $\begin{array}{l}\text { Non-Work-Related } \\
\text { Economic Enhancement. }\end{array}$ & 9 & 7 \\
\hline $\begin{array}{l}\text { Information and } \\
\text { Exchange } . . . \ldots \ldots . . .\end{array}$ & 7 & 6 \\
\hline Self-Actualization... & 6 & 5 \\
\hline Community Service...... & 3 & 2 \\
\hline Total........ & 126 & 100 \\
\hline
\end{tabular}


Several factors need to be discussed concerning Table VII. First, the question citing barriers to services was asked toward the end of the interview. The low level of responses (48 percent) may have resulted from the interviewee wanting to finish the interview.

Second, while not statistically significant, there are some differences between desired services and those that are already being provided. (See Table IV.) Individual and family assistance is the most desired additional service. It is probable that managers sense a need to provide additional services in this category. This also applies to education. There is a low level of services provided in this category and a high level of responses for additional services. The categories of self-actualization and economic enhancement are low in both services provided and additional services requested. It is possible that the 52 respondents did not have an interest in these services or thought that they were inappropriate at the workplace.

The most interesting difference in categories between Tables IV and VII is community service. There is a very high level of community services being provided in most worksites as reflected in Table IV. There is also a very low level of requests for additional services in that category. It is possible that the 52 respondents thought that the worksites were providing an adequate number of services to the community and there was no need to provide additional 
services. This conclusion is inconsistent with the statistics on community involvement discussed earlier. Those statistics pointed out that, although the majority of worksites were aware of problems in the community, only two were actively working with other organizations to address these problems. This discrepancy can be accounted for by reviewing the definitions of community service and community involvement. Community service is defined as "anything that helps out the community or certain institutions." Community involvement, on the other hand, is specifically focused on solving problems in the cormunity. It is probable that the respondents viewed themselves as providing services to the community but not actively working to solve the community's problems.

Problems Which Could Be Addressed At the Worksite

The data in Table VIII is management response to the problems that could be addressed at the worksite. The categories are not mutually exclusive as the respondents may have cited more than one problem. There is little difference between the four most often cited problems (day care, financial, family, and retirement). It is interesting to note, however, that with the exception of financial and recreation, all of the other problems cited by management would be in the category of individual and family assistance. Referring back to Table VII, services in the category of individual and family assistance were also the most often 
requested additional services. Also, the data in Table IV reflects that there are a low number of services provided in this category.

\section{TABLE VIII}

NUMBER AND PERCENTAGE OF PROBLEMS WHICH COULD BE ADDRESSED AT THE WORKSITE, IN RANK ORDER,

AS REPORTED BY 52 MANAGERS

\begin{tabular}{|c|c|c|}
\hline Problem & Number of Responses & Percentage \\
\hline 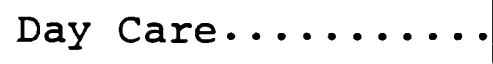 & 20 & 39 \\
\hline Financial.......... & 19 & 37 \\
\hline 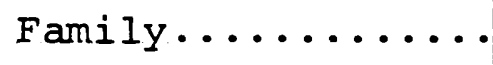 & 16 & 31 \\
\hline Retirement....... & 14 & 27 \\
\hline 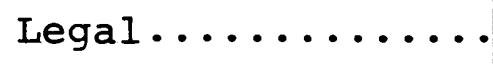 & 13 & 25 \\
\hline Mental Health...... & 13 & 25 \\
\hline Health....... & 13 & 25 \\
\hline Recreation........ & 11 & 21 \\
\hline $\begin{array}{c}\text { Alcohol/Substance } \\
\text { Abuse........... }\end{array}$ & 11 & 21 \\
\hline Other Problem...... & 8 & 15 \\
\hline Don't know......... & 7 & 14 \\
\hline Total & 145 & 280 \\
\hline
\end{tabular}

Note: Total percentage exceeds 100 percent because response categories were not mutually exclusive.

The services in the category of individual and family assistance are directly related to the health and well-being of the employee. As such, these services are important to 
the employees outside of his/her occupation. The needs addressed by responses in Tables VII and VIII overlap from home to work. Respondents may recognize that most employee problems will occur in this category. Their interest in the provision of services in this category may stem from an interest in improving the quality of life for employees.

On the other hand, worksites are not providing services in this category. (See Table IV.) This may result from the fact that from an organizational perspective, these services may not be viewed as the responsibility of the employer.

It is apparent that the 52 management respondents are aware that problems exist in this area. It is also apparent that few worksites are actively trying to address these problems.

\section{COMPARISONS}

The mean number of services per worksite varies according to worksite type, union affiliation, and size. Worksites with the highest mean number of services are large, private-for-profit, and unionized. The lowest mean number of services are found in small, nonprofit, nonunionized worksites. Tables IX, X, and XI present this data according to worksite type, union affiliation, and worksite size respectively. Data displayed in Tables IX, X, and XI are not statistically significant. These tables do, however, provide some interesting items for discussion. 
Table IX shows the total number of services and average number of services by the type of worksite. The mean number of services for all 52 worksites is 23 (22.9) services. There is substantial difference between that number and the highest ( 40 percent) and lowest (13 percent) averages.

TABLE IX

NUMBER AND MEAN NUMBER OF UNDUPLICATED

SERVICES, BY WORKSITE TYPE

\begin{tabular}{l|c|c|c}
\hline $\begin{array}{l}\text { Worksite } \\
\text { Type }\end{array}$ & $\begin{array}{c}\text { Number of } \\
\text { Worksites }\end{array}$ & $\begin{array}{c}\text { Number of } \\
\text { Services }\end{array}$ & $\begin{array}{c}\text { Mean } \\
\text { Number }\end{array}$ \\
\hline $\begin{array}{c}\text { Government.... } \\
\text { Education..... }\end{array}$ & 12 & 245 & 20.4 \\
Nonprofit..... & 12 & 336 & 28.0 \\
Social Service. & 11 & 146 & 13.3 \\
Private-for. \\
Profit....
\end{tabular}

The highest average number of services is in privatefor-profit worksites. There are several possible explanations for this fact. First, these organizations are more likely to have the resources available to provide non-workrelated services. There is also a high level of competition among private-for-profit organizations to recruit new employees. A high level of service provision may be of benefit to the organization in that recruitment process. Second, of the six 
participating private-for-profit organizations, only one is in the small category. Reference to Table $X$ shows that the highest levels of service provision are in medium and large worksites. This could be another explanation for the high number of services in the private-for-profit category.

Finally, it is possible that the six private-for-profit worksites that chose to participate in the survey wanted to demonstrate that they provided a large number of services to its employees. For support of this argument, refer back to an earlier discussion of Table III. In that discussion, reference was made to the fact that there was a possibility that four of the six worksites that chose not to participate may have had few services. The reverse of that argument may apply to the six sites that participated. They do provide a high number of services and they may want that fact known. On the other end of the spectrum is the low level of services offered at nonprofit worksites. Again the question of size needs to be addressed. The majority ( 81 percent) of worksites in the nonprofit category were small. Small worksites had a lower average number of services (18). Also, because of the size and nature of nonprofit organizations in this survey, it is probable that they lack the resources to provide non-work-related services.

Though it is not substantially higher, the average number of services provided at education worksites was higher than the mean number for all worksites (28 percent). Education worksites may have a higher number of services as a 
result of the nature of the worksite. For example, employees may have access to continuing education, physical education facilities and counseling. This does not necessarily result from additional service provision. In fact, most of those services exist for student and faculty use and employees may have access to them as part of their employment. The two other types of worksites, government and social service, are slightly below the mean number of services for the five types of worksites.

Of the 52 worksites in this study, 26 (50 percent) have one or more union affiliations.

\section{TABLE X}

NUMBER AND MEAN NUMBER UNDUPLICATED

SERVICES BY UNION AFFILIATION

\begin{tabular}{r|c|c|c}
\hline Affiliation & $\begin{array}{c}\text { Number of } \\
\text { Worksites }\end{array}$ & $\begin{array}{c}\text { Number of } \\
\text { Services }\end{array}$ & $\begin{array}{c}\text { Mean } \\
\text { Number }\end{array}$ \\
\hline Union...... & 26 & 697 & 26.8 \\
Nonunion.... & 26 & 493 & 10.9 \\
\cline { 2 - 4 } Total.... & 52 & 1,189 & 22.9 \\
\hline
\end{tabular}

This table on service provision in union and nonunion worksites is contradictory to the data presented in the Spiegel study. In that study, spiegel reported that there was a higher level of service provision in nonunion worksites. The conclusions drawn by spiegel were that there may 
have been a higher level of services at nonunion sites in an attempt by those sites to keep workers satisfied. The conclusion that can be drawn from the statistics in this survey is that unions may have a participatory role in developing and maintaining services in the worksite.

Another factor of this analysis is that the majority of unionized worksites would fall in the medium to large size categories. It is not likely that worksites employing only a few people would be unionized. Refering to Table XI, service provision is much higher in medium and large worksites than it is in small worksites. Future research in this area might focus on some of the differences between union and nonunion worksites in an attempt to explore the discrepancy between this study and the Spiegel study.

The final table in this chapter includes comparison data on the number of services provided according to the size of the worksite. There is a wide difference between large and small worksites. Large worksites provided an average number of services (35.3), that is almost twice as high as those provided by small worksites (17.8). There are a number of factors involved.

Large organizations probably have more resources to provide services. This is true of money as well as expertise and personnel. Also, given their size and the number of people they employ, these organizations may be under more pressure from employees to provide service. Competition for qualified employees may also be a factor. Those 
organizations that provide a high level of services may be better able to attract employees. It is also possible that services may be more cost effective in large organizations. For example, an in-house individual and family assistance program for an organization with 2,000 or more employees would probably be more cost effective than contracting out a similar service for 20 employees.

\section{TABLE XI}

NUMBER AND MEAN NUMBER OF UNDUPLICATED

SERVICES BY SIZE OF WORKSITE

\begin{tabular}{r|c|c|c}
\hline Size & $\begin{array}{c}\text { Number of } \\
\text { Worksites }\end{array}$ & $\begin{array}{c}\text { Number of } \\
\text { Services }\end{array}$ & $\begin{array}{c}\text { Mean } \\
\text { Number }\end{array}$ \\
\hline Small... & 32 & 569 & 17.8 \\
Medium... & 9 & 232 & 25.8 \\
Large.... & 11 & 388 & 35.3 \\
\cline { 2 - 4 } Total. & 52 & 1,189 & 22.9 \\
\hline
\end{tabular}

On the opposite end of the scale, of course, are the small organizations. In many cases, services may not be appropriate for these organizations. Not only do these worksites lack the resources to provide service, they are probably less motivated to do so. They are less likely to be unionized and statistics cited earlier indicate that in this survey there are more services in union worksites. Also, employees and management may both agree that services in an organization 
of that size are inappropriate. For example, a credit union for financial assistance may be perfectly appropriate for the large employer, and absolutely ridiculous for the small employer. Even things as simple as a vending machine or a parking lot may be a necessity in a large organization and frivolous and non-essential in a small organization. This is an area for further study.

\section{SUMMARY}

The analysis of most of this suggests future research and research questions. Aside from the question of significance, there are many interesting points of analysis. The intent of this survey was to document the types and frequencies of services currently being provided in the Tri-County area, and this goal has been accomplished. This analysis has attempted to point out trends, discuss discrepancies, and delineate tendencies in the data presented. It is hoped that this survey will serve as one of the foundation pieces for future research and analysis.

Some of the data gathered by the research team has been omitted from the analysis. The reason for this was a very real time limitation. The research team had only six months to complete this project and an analysis of all of the data available was not possible. It was not the intention of the study to deliberately omit significant data, but rather to analyze the most important data. 
CHAPTER V

IMPLICATIONS OF THE WORKSITE STUDY

The Employment and Training Report of the President estimates that over 95 million people were employed in the United States in 1978 (1979, p. 4). The growing importance of work in an individual's life means that the workplace has become one of the major socializing institutions in this society, taking its place alongside the family, the school, and the church or synagogue. In this highly mobile, dynamic society, the workplace has, in a sense, replaced the neighborhood as the central point of contact for people and as the dissemination of community information. This growing change is reflected in the fact that the top four service categories provided at or through the workplace parallel activities which might be provided through a neighborhood activity center or the neighborhood itself: workplace amenities, recreation, community service, and information and exchange. While it is true that these services represent "safe," low cost, non-controversial activities, it nevertheless is a clear statement that the workplace is an important source of social support for most working Americans.

However, the data in this study seem to echo spiegel's conclusions that the workplace is an under-utilized arena 
for the discharge of services (1974). With the significant changes in the American workforce and changing workers' needs, business and industry would be wise to look into how services might impact in a positive way on employees. For example, given the increase of women in the labor market, it is not surprising that in this study day care was cited as the number one problem which could be addressed at the worksite. Workers in this study requested additional services in the area of financial and individual and family assistance. This data coincide with literature on existing social service industrial programs which dealt primarily with socio-environmental and financial problems (Weissman, 1976), and more specifically with marriage and family issues, alcohol, the law, finance, and drug abuse (Skidmore, Balsam, and Jones, 1974; Cutting and Prosser, 1979).

It would be simple to recommend the Oregon worksites begin to incorporate service components into their programs. However, most Oregon employment sites are not large units (as defined by spiegel), and according to management speculation, cost is a major factor in determining whether or not service is provided. Therefore, more research needs to be done before solid recommendations can be made.

The exploratory nature of this study raised many questions which may be addressed in future research studies. Some of the salient questions are as follows: 
1) What is the quality of services currently being provided and what is the utilization rate of these services? What are the factors which influence service quality and utilization rates, and is there a relationship between the two entities?

2) Of those worksites currently providing an array of services to employees, which departments are responsible for the implementation of these services, and how are these services monitored? For example, a staff person in the personnel department of a large company might be responsible for new employees who are usually concerned with relocation, housing, finances, and new roles and expectations. A different staff person may be responsible for employee benefits, and may see retiring employees concerned with relocation, housing, finances, and new roles and expectations. How does the provision of services affect quality and utilization rates? How does it affect the role definition of the industrial social worker as a potential service provider?

3) What is the role of the industrial social worker in increasing management and staff awareness of the importance of services through the workplace? As indicated earlier, the major barriers to service provision, aside from a lack of money, were a lack of interest by management and staff, and attitudes that services were inappropriate at the workplace. Literature is replete with warnings that much of the successes and failures of industrial social 
service programs are directly related to the degree of management and supervisory support (Brooks, 1975; Lepkins, 1975; Stone and Crowthers, 1972; Bowler, 1980).

4) Given the potential barriers to the provision of services at or through the workplace, how might a comprehensive EAP be effectively introduced into a worksite? What are the components of a well-researched EAP system? The March-April, 1981, issue of Alcoholism magazine features a 22-step model in the development of an EAP system, beginning with getting support and commitment from management and ending with a cost-benefit analysis. The introduction of the actual service delivery program to employees is the 16 th step in this model.

5) What kind(s) of comprehensive needs assessment tool might be developed in order to plan services for employeebased needs? What is the role of the industrial social worker in this process?

6) What is the role of professional social work in rendering services to workers and intervening in a system which is being forced to address socio-environmental issues as well as production issues? How might the expertise of the social work profession be effectively utilized to maximize the "humanization" of the workplace? What are the range of activities necessary in the achievement of this goal?

The findings of this study seem to indicate that it is the private-for-profit organizations which are assuming 
leadership roles in initiating programs focused on the nonwork related needs of the employees. In these times of restricted federal and state funding and economically tight spending, it is not surprising that private industries are the forerunners in the provision of social services at or through the worksite. In the past, human services professionals and business and industry have treated each other with disdain at worst, or caution at best. The development of human services into the world of work has created an emerging partnership between these two groups, with social workers staking out claims in this area.

Social work's entry into the world of work necessitates new techniques and skills in the area of personnel management, labor relations, community organization, the legislative process. Viewed in this light, the standard two-track system in most MSW programs, which separates direct service from planning/management, is detrimental to the student with an industrial focus. Schools of social work, then, need to keep current with this growing trend by redesigning curricula and incorporating the two-track system into one integrated program.

In the final analysis this study proposes that the question, "How much responsibility should the workplace assume in addressing employees' personal needs?" has not been resolved. While the study lacks clear, statistically significant outcomes, what is evident is the continuing conflict 
over how basic human needs should be met. The fact that this study reflects that many large worksites are assuming some of this responsibility is encouraging. However, before the social work profession can successfully introduce services into the workplace, it must first address this issue of responsibility. 


\section{SELECTED BIBLIOGRAPHY}

Akabas, Shiela H. and Hyman J. Weiner, "Work in America: The View from Industrial Social Welfare.: Unpublished paper, Columbia University School of Social Work, N. Y.: 1974.

Akabas, Shiela H. "Fieldwork in Industrial settings: Opportunities, Rewards, and Dilemmas," Journal of Education for Social Work, 14 (1978): 13-19.

Akabas, Shiela H., Paul A. Kurzman, and Nancy Kolben, (Eds.) Labor and Industrial Settings: Sites for Social Work Practice. New York: Council on Social Work Education, 1979.

Alcoholism/The National Magazine, March/April, Foundation for Alcohol Communication.

Alexander, Linda. "Social Work's Freudian Delude: Myth or Reality?" Social Service Review, (Dec. 1972): 517-532.

Almquist, Elizabeth M. Minorities, Gender and Work. Massachusetts: Lexington Books, 1979.

Anderson, Nels. Dimensions of Work. New York: David McKay Co., Inc., 1964 .

Bakalinsky, Rosalie. "People vs. Profits: Social Work in Industry." Social Work, 25 (Nov. 1980): 471-475.

Best, Fred, (Ed.) The Future of Work. New Jersey: PrenticeHall, 1973.

Blauner, Robert. Alienation and Freedom: The Factory Worker and His Industry. Chicago: University of Chicago Press, 1964 .

Blomquist, David C., Daniel D. Gray and Larry L. Smith. "Social Work in Business and Industry," Social Casework, 3 (Oct. 1979): 457-462.

Bowler, William M. "Prevention in the Industrial Environment," Rural Connections, 1 (Sept. 1980): 1-2.

Brandes, Stuart. American Welfare Capitalism 1880-1940. Chicago: University of Chicago Press, 1970. 
Braude, Lee. Work and Workers. New York: Praeger Publishers, Inc., $19 \overline{75 .}$

Brooks, Paul R. "Industry-agency Program for Employee Counseling," Social Casework, 56 (July 1975): 404-410.

Bryant, Clifton D., (Ed.) The Social Dimensions of Work. New Jersey: Prentice-Hall, 1972.

Cahn, Ann F., (Ed.) Women in the U. S. Labor Force. New York: Doubleday Co., 1962 .

Cutting, Allan R., Prosser, Frank J. "Family Oriented Mental Health Consultation to a Naval Research Group." Social Casework, Vol. 1, No. 4 (1979).

Deans, R. C. American Work Ethic. New York: Congressional Quarterly, Inc., 1973 .

DeGrazia, Sebastian. Of Time, Work, and Leisure. New York: Doubleday Co., 1962 .

Erickson, Erik H. "The Problem of Ego Identity," Psychology of Society, Richard Sennett, (Ed.,) New York: Vintage Books, 1977.

Gilbert, Neil and Harry Specht. Dimensions of Social Welfare Policy. Englewood Cliffs, N. J.: Prentice-Hall, Inc., 1974 .

Ginzberg, Eli and Human Berman. The American Worker in the 20th Century. U.S.A.: Free Press of Glencor Collier Macmillan Ltd., 1964.

Googins, Bradley. "Employee Assistance Programs," Social Work 20 (November 1977): 464-467.

Harbeson, Gladys Evans. Choice and Challenge for American Women. Massachusetts: Schenkman Publishing Co., 1967.

Hareven, Tamara K. and Randolph Langenbach. Amoskeag. New York: Pantheon Books, 1978.

Heron, Alexander R. Why Men Work. Stanford: Stanford University Press, 1948 .

Heyman, Margaret M. "Employer Sponsored Programs for Problem Drinkers," Social Casework, 52 (Nov. 1971): 549.

Holden, Constance. "Alcoholism: On the Job Referrals Mean Early Detection," Science, 179 (1973): 413-415. 
Howe, Louise $K$. Pink Collar Workers. New York: G. P. Putnam's Sons, 1977.

Kennecott's Cure for People Problems, Business Week, (April 15, 1972): 113-114.

Komarousky, Mirra. The Unemployed Man and His Family. New York: Octagon Books, 1971.

Lee, Gregory M. "Industrial Social Work: A Review of the Literature and an Evaluation of an Employee Assistance Program," Master's thesis, Portland State University, 1979.

Leeman, Calvin P. "Contracting for an Employee Counseling Service," Harvard Business Review, 2024 (March-April 1974) : $152-154$.

Lepkins, Milton. "A Program of Industrial Consultation by a Community Mental Health Center," Community Mental Health Journal, 11 (1975): 74-81.

Levitan, Sar A., and William B. Johnston. Work is Here to Stay, Alas, Salt Lake City, Utah: Olympus Publishing Co., 1973.

Liebow, Elliot. Tally's Corner. New York: Little Brown and Co., 1967.

Lotterhas, Jerry G. "Historical and Sociological Perspectives of Alcohol-Related Programs," Occupational Alcoholism Programs, Richard L. Williams and Gene H. Moffat, (Eds.) Springfield, Ill.: Charles C. Thomas, 1975.

Mandilovitch, Martha. Worker's Attitudes Toward Work, Self, and Life: the Effects of Work and Education, New York: Columbia University, 1977.

Mayer, John E. and Noel Timms. The Client Speaks. New York: Atherton Press, 1970.

McLean, Alan A. "Occupational Mental Health; Review of an Emerging Art," The American Journal of Psychiatry, $122(1966): 961-975$.

Meenaghan, Thomas M. and Robert $O$. Washington. Social Policy and Social Welfare. New York: Free Press, 1980.

Mill, John Stuart. "The Subjection of Women," Psychology of Society, Richard Sennett, (Ed.) New York: Vintage Books, 1977. 
Mills, Elizabeth. "Family Counseling in an Industrial Job Support Program," Social Casework, 53 (1972): 587-592.

Morse, Dean. The Utilization of Older Workers. Washington: National Commission for Manpower Policies, U. S. Government Printing Office, 1979.

Neff, Walter S. Work and Human Behavior. New York: Atherton Press, 1968.

O'Toole, James (Ed.) Work and the Quality of Life. Massachusetts: MIT Press, 1974.

O'Toole, James. Work, Learning and the American Future. San Francisco: Jossey-Bass Publisher, 1977.

Ozawa, Martha N. "Women and Work," Social Work, 21 (1976): 455-462.

Ozawa, Martha N. "Development of Social Services in Industry: Why and How?" Social Work, 25 (Nov. 1980): 466-470.

Perlis, Leo. "Human Contract in the Organized Workplace," Social Thought, 3 (Winter 1977): 29-35.

Perlis, Leo. "Industrial Social Work - Problems and Prospects," NASW News, (May 1978).

Ramirez, Bruno. When Workers Fight: The Politics of Industrial Relations in the Progressive Era: 1898-1916. Westport, Conn:: Greenwood Press, 1978 .

Reid, William J. and Laura Epstein. Task-Centered Casework. New York: Columbia University Press, 1972.

Shrank, Robert. Ten Thousand Working Days. Massachusetts: MIT Press, 1978 .

Selltiz, Claire, Lawrence S. Wrightsman and Stuart W. Cook. Research Methods in Social Relations. 3rd ed. New York: Holt, Rinehart and Winston, 1976.

Sennett, Richard and Jonathan Cobb. The Hidden Injuries of Class. New York: Random House, Inc., 1972.

Sennett, Richard, (Ed.) The Psychology of Society. New York: Vintage Books, 1977.

Skidmore, Rex, Daniel Balsam and otto F. Jones. "Social Work Practice in Industry," Social Work, 19 (May 1974): 280-286. 
Spiegal, Hans. Not for Work Alone: Services at the Workplace. New York; Urban Resource Center of Hunter College, 1974.

State of Oregon, Employment Division. Oregon Covered Employment and Payrolls by Industry and County. 4th quarter, 1977.

Stone, Judson L. and Virginia Crowthers. "Innovations in Programming and Funding of Mental Health Services for Blue-Collar Families," American Journal of Psychiatry, 128 (1972): 1375-80.

Terkel, Studs. American Dreams: Lost and Found. New York, Pantheon Books, 1980 .

Tiffany, Donald, James R. Cowan and Phyllis M. Tiffany. The Unemployed: A Social-Psychological Portrait. Englewood Cliffs, New Jersey: Prentice-Hall, Inc., 1970.

Tilgher, Adriano. "Work Through the Ages," Man, Work and Society. S. Nosow and W. H. Form, (Eds.) New York: Basic Books, 1962.

Turner, John B., (Ed.) Encyclopedia of Social Work. New York: National Association of Social Workers, 1977.

U. S. Department of Labor, and U. S. Department of Health, Education and Welfare. Employment and Training Report of the President. (Publication No. 029-000-00359-9), Washington, D. C.: U. S. Government Printing Office, 1979.

Vantil, Sally Bould. Work and the Culture of Poverty: The Labor Force Activity of Poor Men. San Francisco:

R. \& E. Research Association Press, 1973.

Weiner, Hyman J., Shiela Akabas and John H. Sommer. Mental Health Care in the World of Work. New York: Association Press, 1973.

Weissman, Andrew. "A Social Service Strategy in Industry," Social Work, 20 (1975): 401-403.

Weissman, Andrew. "Industrial Social Services: Iinkage Technology," Social Casework, 57 (1976): 50-54.

Westcott, Diane N. Questions and Answers on Popular Labor Force Topics. Washington, D.C.: U. S. Department of Labor and Statistics, (Report 522) 1978.

Wilcock, Richard C. Unwanted Workers: Permanent Layoff and Longterm Unemployment. New York: Free Press of Glencore, 1963. 
Wolfbein, Seymour L. Work in American Society. Illinois: Scott Foreman and Co., 1971. 
APPENDICES 
APPENDIX A

Date

M. $Y$

Business $\mathrm{X}$

Address

City, state

Dear M. Y:

A select group of students in the Master of Social Work Program at Portland state University are engaged in an important study pertaining to employee services offered at the workplace. They are in the process of interviewing people at a number of worksites. Your workplace has been selected, and I am eager to solicit your participation in this research. In the interest of confidentiality, the names of worksites and all interviewees will remain anonymous during the study and in the final report.

For the purposes of this study, , one of the research team members, would like to interview a minimum of two representatives of your worksite. One of them must be at the management level. If your employees are represented by one or more unions, the interviewer would also like to interview the shop steward(s).

The interviewer would like to visit your worksite one day between (date) and (date) $\mathrm{S}(\mathrm{H}) \mathrm{e}$ will call you to arrange a day and time convenient for you.

I want to thank you for your cooperation in assisting us with this research. At the conclusion of our study, I will send you a summary of our findings which I hope will be of interest and use to all.

Sincerely yours,

Norman I. Wyers, D.S.W. Associate Professor 
APPENDIX B

INFORMED CONSENT

I,

hereby agree to serve as a subject in the research project on Services at the Workplace under the supervision of Norman Wyers, D.S.W.

I understand that the study involves personal interviewing only.

I understand that the only possible risk to me associated with this study is the demand on my time.

It has been explained to me that the purpose of the study is to learn about the existence of services in the workplace.

I may not receive any direct benefit from participation in this study, but my participation may help to increase knowledge which may benefit others in the future. has offered to answer any questions I may have about the study. I have been assured that all information I give will be kept confidential and that the identity of all subjects will remain anonymous.

I understand that I am free to withdraw from participation in this study at any time without jeopardizing my 
relationship with my place of work.

I have read and understand the foregoing information.

Date Signature

If you experience problems that are the result of your participation in this study, please contact Richard streeter, Office of Graduate Studies and Research, 105 Neuberger Hall, Portland State University, 229-3423. 
I am aware that the management of this worksite has given my name, and their permission, and that my responses will be confidential. I further understand that this interview should last approximately one hour.

\section{Signature}

Date 
APPENDIX C

DEFINITIONS

1. Self-Actualization

Spiegel: Activities that tend to help facilitate personal fulfillment and that help to realize the individual's creative potential through self-expression or that highlight of his own awareness of others and their needs as his own. (p. 58)

Lay Definition: Activities that help a person feel better about him/herself, help express creativity, or become aware of the needs of others.

Examples: Bible study, women's liberation group, group session on improving interpersonal communication.

\section{Education}

Spiegel: Employer or Union efforts that encourage or financially support formal teaching-learning enterprises by the employee and/or his family. Some of these activities are conducted at the workplace by the employer or at an outside organization, while others are discharged through accredited educational institutions. (p. 66)

Lay Definition: The worker and/or his/her family gets encouragement or money to further his/her education. This can be through classes given at or off the worksite.

Examples: educational subsidies, scholarships, classes offered at the worksite, i.e., cooking, tennis, golf.

\section{Individual and Family Assistance}

Spiegel: Service provided to employees and their families to respond to health, welfare, personal, psychological and related need; the services should help the individual employee deal with non-work needs in the category by either maintaining or preventing the occurrence of problems or by actively assisting and helping the individual once the problem has arisen. (p. 61) 
Lay Definition: Services to help workers and their families deal with health, money, personal, and psychological needs. These needs are not directly related to work. Services help prevent the problem or get rid of it once it occurs.

Examples: first aid station, visiting nurse, drug abuse treatment, referral service.

4. Information and Exchange

Spiegel: Mechanisms by which written and verbal information concerning non-work-related activities is disseminated at the workplace. (p. 69)

Lay Definition: The way workers find out about things (activities) that aren't going on at work.

Example: bulletin boards, speakers, lectures, films, brochures.

5. Non-Work-Related Economic Enhancement

Spiegel: Activities designed to enable the individual to maximize his disposable income through the availability of subsidized commercial services such as banking, savings arrangements, discourts, financial advice, transportation assistance and similar indirect economic assistance. (p. 73)

Lay Definition: Activities that help the worker to manage and/or save his/her money.

Examples: banking services, discount tickets, group vacations.

\section{Workplace Amenities}

Spiegel: The facilities at the worksite which enhance and encourage employee non-work-related activities. These facilities may include the availability of equipment and environmental amenities designed to further relaxation, group interaction, or other personal agendas. These facilities may be provided free of charge or on a subsidized basis for employees only, their families, or in some cases, for the community at large. Also included are technical services provided by one employee to another at the worksite.

Lay Definition: Any facility at the jobsite that helps the worker with non-work-related activities. These can be for things like the workers' relaxation, group meetings, or other 
things. They may be free to the worker or at a cheaper rate. These may be offered to the worker alone or his/her family, or even the community. This also includes services provided from one worker to another.

Examples: locker rooms, lounges, parking facilities, vending machines.

\section{Community Service}

Spiegel: Voluntary activities designed to enhance the community where the firm is located or where employees reside, or to enhance specific institutions or population groups in such communities. These activities may be initiated by the firm, the employees, or upon special requests, from either the public or private sectors in such communities. (p. 49)

Lay Definition: Anything that helps out the community or certain institutions. These activities can be started by the company, the employees, or people in the community.

Examples: speakers to schools, use of company facilities for community.

\section{Recreation and Entertainment}

Spiegel: Activities that include athletic, social, cultural and leisure time pursuits of employees and their families taking place at the firm's, the union's, or the community's facilities.

Lay Definition: Any type of recreation or entertainment for the workers and/or their families, on or off the worksite.

Examples: softball teams, hobby clubs, Fourth of July celebration. 
APPENDIX D

COPY OF INTERVIEW SCHEDULE 
APPENDIX D

SERVICES AT THE WORKPLACE:

Multnomah, Clackamas, Washington Counties

OREGON

\section{PURPOSE:}

This research project will survey approximately 60 worksites in Multnomah, Washington, and clackamas Counties to determine the kinds of non-work-related services offered at the workplace.

"Non-work-related services" will be defined as organized activities at or through the workplace whose primary purpose does not aim at the on-the-job productive capacity of the employer, but rather towards the off-the-job needs and interests of the person.

\section{SELECTION PROCESS:}

Worksites with varying numbers of employees were selected in the Tri-County area, and are representative of the public and private sectors, profit and nonprofit organizations. The research team will interview one management and nonmanagement employee, as well as the shop steward(s) where employees have union representation.

\section{CONFIDENTIALITY:}

The names of all interviewees and worksites are strictly confidential.

\section{USE OF REPORT FINDINGS:}

This research will provide the first comprehensive description of non-work-related services at the workplace in the TriCounty area. Findings may have implications for social work practice in industrial settings. A summary of the research will be sent to each participating worksite, while the document itself will be placed in the Portland State University Library. 
LENGTH OF INTERVIEW:

This interview will take approximately one hour to complete. Your participation in this study has been approved by your organization. 
Service Definitions:

\section{Recreation and Entertalnent}

Any type of recreation or entertalnment for the workers and/or their famtlles, on or off the worksite.

Examples: softball teams, hobby clubs, Fourth of July celebration

$\longrightarrow$

II. Education

The worker and/or his/her famtly gets encouragenent or money to further hIs/her educet1on. This can be through classen given at or off the workst te.

Examples: educational subsidies, scholarships, classes offered at the works1te, 1.e. cooking tennis, golf

\section{Communitr Service}

Anything that helps out the community or certain institutions. These activ Itles can be started by the company, the employees, or people in the cominity.

Examples: speakers to schools, use of coapany fac1litles for communtty activites, tive off for ctolc affatrs.

\section{Information and Exchange}

The way workers find out about things (activities) that aren't going on at work.

Example: bulletin boards, speakers, lectures, f1lm, brochures

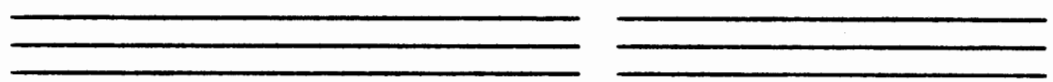

\section{Workplace Amenteles}

Any fac1lity at the jobsite that helps the worker with nowrorik related actIVitles. These $c a n$ be for thing like the wortere relaration, group neetings, or other things. They may be free to the worker or at a cheaper rate. These may be offered to the worter alone or hls/her fandly, or even the coumingt. Th1s also Includes services provided from one worter to another.

Examples: locker roon, lounges, parking factlities, vending machines

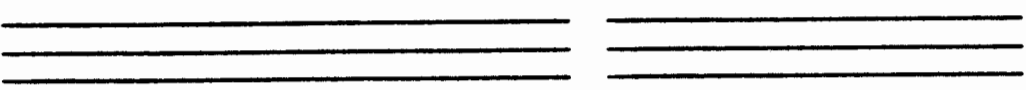

\section{Self Actual1zation}

Activities that help a person feel better about hider self, help expesa creativity, or becow arare of the needs of others.

Examplea: Group sesston on Improving interpersonal comaunfcation, self help groupe, B1b le study

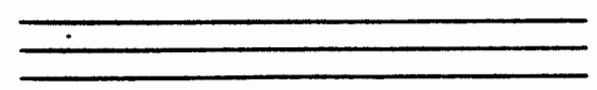


VII. Individual and Fandy Assistance

Services to help workers and thelr fartiles deal with health, money, personal and psychologdcal needs. These needs are not directly related to wort. Services that help prevent the probles or get rid of it once it occurrs.

Examples: firat afd station, visting nurse, drug abuse treatment, referral serotice
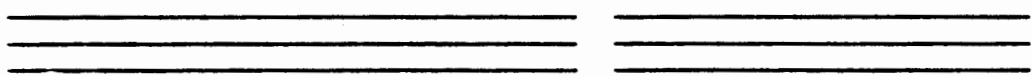

VIII. Non Work Belated Economic Enhancement

Actioltes that help the worker to anage and/or save hls/her money.

Examplea: banking services, discount tickets, group vacations

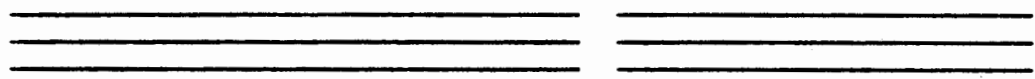


Manager

Labor

Union

A. What services in this category are offered here?

1.

2.

3.

6.

6.

(ASK B-J FOR EACH SERVICE)

$B$. When was this service initiated?

(ASK FOR APPROXIMATE YEAR)

1.

3.

4.

5.

6.

C. Who initiated this service? Where did the idea for this service come from?

Management

Union

Staff

Outside source

$\mathrm{D} / \mathrm{K}$

Other

Comments:

D. What was the reason this service was started?

1.

2.

3.

4.

5.

ธ.

E. How is this service financed? Who pays for it?

All employer

All employee

Shared employee/employer

Vending machines

Outside source

Fund raising activities

$\mathrm{D} / \mathrm{K}$

other
F. What form of payment is used? How is the money collected for this service?

Payroll deduction

Voluntary contribution

Fee schedule

Free

Employee fund

Union fund

D/K

other

Comments:

G. How much do you think the workers use the service?

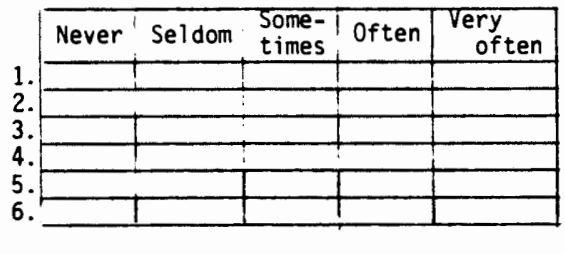

Comments:

H. How much do you think management uses the service?

\begin{tabular}{l|l|l|l|l|l|}
\hline $\begin{array}{l}\text { Very } \\
\text { often }\end{array}$ & Often & $\begin{array}{l}\text { Some- } \\
\text { times }\end{array}$ & Seldom & Never \\
\hline & & & & \\
\hline & & & & \\
\hline & & & & \\
\hline & & & & \\
\hline & & & & \\
\hline & & & & \\
\hline
\end{tabular}

Comments: 
1. How satisfied, in your opinion, do you think workers who use the service are with the service?

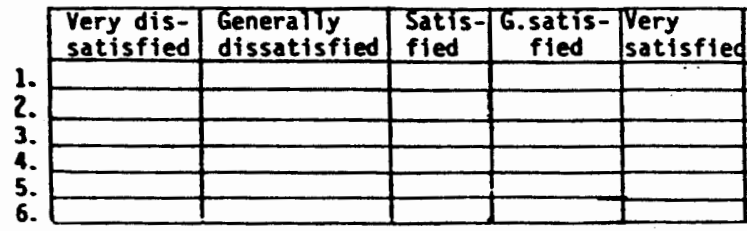

Comments:

J. How satisfied do you think management is with the service:

\begin{tabular}{|l|l|l|l|l|}
\hline $\begin{array}{l}\text { Very } \\
\text { satisfied }\end{array}$ & $\begin{array}{l}\text { Generally } \\
\text { satisfied }\end{array}$ & $\begin{array}{l}\text { Satis } \\
\text { fied }\end{array}$ & $\begin{array}{l}\text { G.dissatis- } \\
\text { fied }\end{array}$ & $\begin{array}{l}\text { Very } \\
\text { dissatid }\end{array}$ \\
\hline & & & & \\
\hline & & & & \\
\hline & & & & \\
\hline & & & & \\
\hline & & & & \\
\hline & & & & \\
\hline
\end{tabular}

Comments:

K. Generally. are services evaluated?
Yes
No.
Don't know

If so, who evaluates them?

Users

Staff

Unton

Management

Program eva Tuators/consultants

Don't know

Other

L. How are these services evaluated?

Surveys

Formal meetings

Informal meetings

Utilization rates

Cost/effective analysis

Goal achievement

Don't know

Other 
IX. A. What 5 additional services do you think could be offered. through the workplace? If anything weze possible what services could be provided here? (IIST UNDER APPROPRIATE CATEGORY)

Recreation and Entertainment

Education

Community Service

Information \& Exchange

Workplace Amenities

Self-actualization

Individual \& Family Assistance

Non-work Related Economic Exchange

Other

IX. B. Please prioritize this list. Which do you think is the most important? Second? Third? and so on. (NUMBER ABOVE AS RESPONDENT ANSWERS THIS QUESTION)

X. A. What problems have been encountered in initiating services What barriers have there been to starting services? (READ THE LIST OF POSSIBILITIES BEIOW AND ASK IF ANY OP THEM-MIGHT APPLY. CHECK THOSE THAT APPLY)

1. Iack of interest by a)Union b) Management c) Staff

2. Iack of regources a)money c) Other(LIST EXAMPLES GIVEN) b) expertise

3. Labor disputes

4. Unaware that services are needed

5. Think that services are not appropriate at the workplace

6. Don't know

7. Other (LIST EXAMPLES GIVEN)

Comments:

XI. A. Once the service has been initlated what-problems have been encountered in providing services. (READ THE IIST OP POSSIBILITIES BELOW AND ASK IF ANY OF THEM MIGHT APPLY. CHECK 'THOSE THAT DO.)

1. Lack of coordination

2. Lack of expertise

3. Lack of time

4. Lack of space

5. Ineffectiveness of service

6. lack of interest by a) labor

7. Lack of money

8. Don't know

9. Other

Comments(FOR* QUESTION FURTKER) 
XII. A. Are there services which have been requested and no: provided? Have thore been any, 3 leas for services that have not been acted upon?

1.

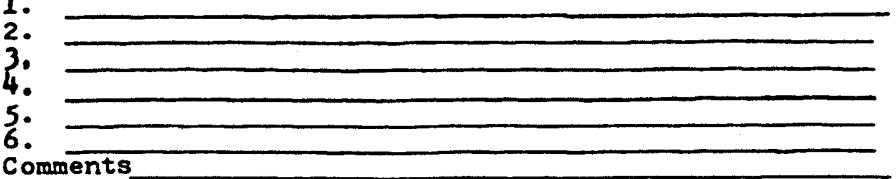

Comments

XIII A. We are interested in the relationship of this workplace to your community. We define community as the neighborhood (area) within three miles of your workplace. What problems do you consider most pressing to this community? (CHECK

iTAR BELOW) THOSE THAT APPLY)

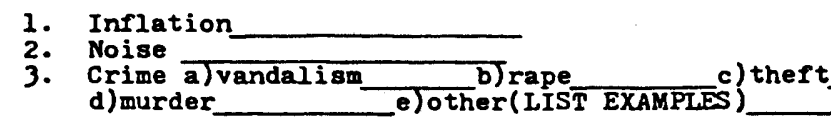

4. Unemployment

5. Transportation

6. Safety

7. Recreation

8. Housing

9. Poverty

10. Parking

11. Don't know

12. Other (LIST EXAMPLES)

Comments

XIII.B. Does your organization address any of these problems? (STAR THOSE IN XIII.A. THAT THEY ADDRESS. CHECK APPROPRIATE RES PONSE BELOW)

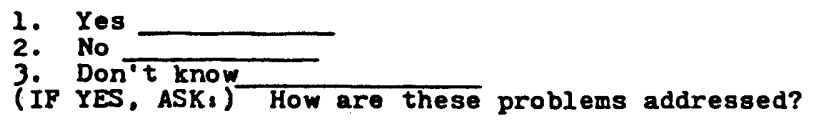

Other comments:

XIII.C. Do you know of any organizations th.t address themselves to these problems?
1. Yes
2. No
3. Don't Know
Comments

XIII.D. Does your organization work with any other organizations that provide services to the community? Does your organization coordinate with other organizations currently involved in comnunity service?

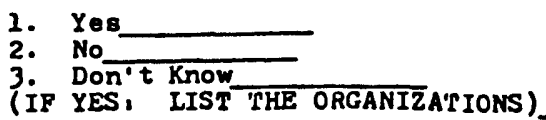


XIV. A. We have talked a lot about many different services offered here and we are interested in what other services could be offered. What non-work related problems do you see that members of your organization have that might be remedied or helped at the workplace? (CHECK THOSE THAT APPLY)

1. Family

3. Legal

5. Retirement

7. Day care

2. Pinancial

4. Health

6. Recreation

8. Mental health

Alcohol/substance abuse

10. Don't know

11. Other

Comments

YV A. (THIS QUESTION IS TO ASKED ONLY IF YOU FIND AFTER DISCUSS ION IN QUESTION I THAT THERE ARE NO SERVICES AT THE SITE.) In your opinion, under what circumstances would services be provided at or through the workplace? 
Interviewer:

Date :

WORKSITB INPORMATION SHEET

XVI. A. Name of worksites

XVII A. Description of workplace, (CHECK CORRECT REPLY)

1. Government

2. Private for profit

3. Education

4. Private non profit

5. Social Services

6. Large

7. Medium

8. Small

xVIII. A. Total number of employees:

XIX. A. Number of women to number of mens (REPLY CAN BE EITHER IN NUMBER OR RATIO)

Ratio yen Women Number Nen

XX. A. Racial composition (REPLY CAN BE IN EITHER NUMBER OR RATIO)
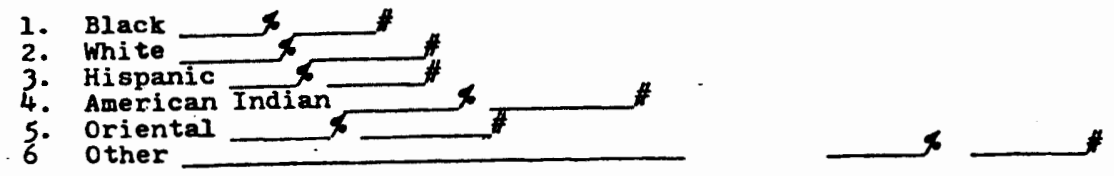

XXI. A. Age of workplace (CHECK CORRECT REPLY)
1. 10 years. or 1 ess
2. 11 years to 20 years
3. 21 years to 30 years
4. 31 years to 40 years
5. 41 years to 50 years
6. 51 years and over

XXII. A. Description of workforce (REPLY CAN BE EITHER IN NUMBER OR PERCENTAGES)

1. Age 18-24

2. Age 25-40

3. Age $41-55$ and above

Age 56 and above

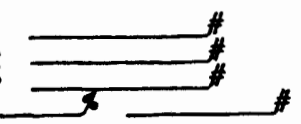

XXIII.A. Average years of education

Management:

1. Graduate from 8th grade

2. Graduate from 12 th grade

3. Graduate from College

4. Post-graduate degree
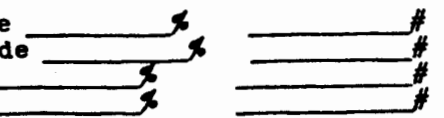

Non-management:

1. Graduate from 8 th grade

2. Graduate from 12 th grade

3. Graduate from college

4. Post-graduate degree

XXIV. A. Average yearly income

Management:

1. $0-\$ 5.000$

2. $\$ 5,001-\$ 10,000$

3. $\$ 10,001-\$ 15,000$

4. $\$ 15,001-\$ 20,000$

5. $\$ 20,001-\$ 25,000$

6. $\$ 25,001$ and above

s

\% 8
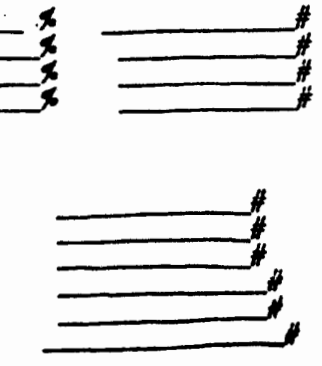
XXIY. A. CONTINUED

\section{Averege yearly income}

non-management:

2. $\$ 5,001-\$ 1 \overline{0,000}$

3. $\$ 10,001-\$ 15,000$

4. $\$ 15,001-\$ 20,000$

5. $\$ 20,001-\$ 25,000$

6. $\$ 25,001$ and above

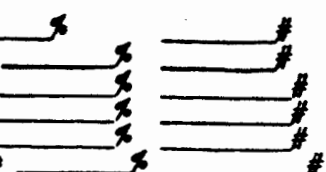

XXV. A. Estimated annual turnover rate

XXVI. A. Union affiliation of workers (CHECK CORRECT REPLY)

2. Yes

XXvII. A. Predominate residence of workers

1. 1-3 miles from worksite

2. 3-10 miles from worksite

3. Over 10. miles from worksite 